\title{
The U.S. Economy, Public Policies, and the Dollar as an International Currency Reserve
}

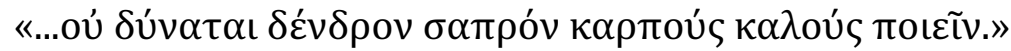

\author{
Dr. Ioannis N. Kallianiotis \\ Economics/Finance Department \\ The Arthur J. Kania School of Management \\ University of Scranton. Scranton, PA 18510-4602
}

\begin{abstract}
${ }^{1}$
The "innocent" outsourcing, the creeping globalization, and the "guilty" latest global financial crisis have caused serious and lasting socio-economic problems to the U.S. The current account deficit (consumption exceeds production in the U.S.), which causes a capital account surplus (capital inflows in the U.S.) and the scale of financing needed to support the U.S. fiscal deficit (and the private sectors and households debts) together with the Federal Reserve's policy of keeping U.S. interest rates low for ten years to ward off deflation, to stimulate the financial markets, and to revive growth, has revived concerns about a sudden and sharp depreciation of the U.S. dollar, an increase in inflation, and a new burst of the current bubble in the financial market, which will cause a global depression. Americans have lost an enormous amount of their purchasing power and wealth during the last 90 years, due to seven financial crises. The wars in Iraq, Afghanistan, Syria, and Libya have turned Muslim investors to other currencies holdings instead of the U.S. dollar. This article examines potential triggers and indicators of such a crisis and posits concrete policy options to limit U.S. vulnerability, due to loss of manufacturing and to the possibility of a plummeting dollar. But, even with a depreciated dollar, the U.S. economy cannot compete with the Chinese one because the cost of production in China is less than 1/10 of the U.S. cost. U.S. has to maximize the social welfare of the country, which means to protect its domestic industries and sectors of the economy. It argues that the obvious long-term response to the risk of a dollar crisis and deterioration of the U.S. welfare is to limit buildup of the United States' external debt (trade deficits) and domestic ones (public and private debts), and recommends that larger reserves (and well-understood mechanisms for borrowing foreign exchange reserves from major foreign central banks) would help to reduce the United States' vulnerability to such a crisis. As a debtor, the U.S. is benefited from the devaluation of its currency and from the protection of its domestic manufacturing.
\end{abstract}

Key Words: Estimation, Time-Series Models, Forecasting and Other Model Applications, Consumption and Saving, Interest Rates, Central Banking, Monetary Policy, International Trade Policy Protection, International Policy Coordination

JEL (Classification): C13, C22, C53, E21, E43, E52, F13, F42

\section{ECONOMIC ENVIRONMENT AND JUSTIFICATION OF DOLLAR'S DEPRECIATION}

The U.S. dollar has shown a large volatility even before 1971, when the gold exchange standard was abandoned by President Nixon ${ }^{2}$ and continued since 1973, when the exchange rate

\footnotetext{
${ }^{1}$ Economics/Finance Department, The Arthur J. Kania School of Management, University of Scranton, Scranton, PA 18510, U.S.A. I would like to acknowledge the assistance provided by Jaclyn A. Taravella and Janice Mecadon. Financial support (professional travel expenses, submission fees, etc.) was provided by Provost's Office (Faculty Travel Funds, Henry George Fund, and Faculty Development Funds). The usual disclaimer applies. Then, all remaining errors are mine.
} 
became flexible. The value of the dollar can be seen by looking at the different exchange rate indexes. The Trade Weighted Exchange Index (USXRI) ${ }^{3}$ has during this period a mean value, USXRI $=96.44901$ and a standard deviation, $\quad$ USXRI $=14.24779$. Its maximum value was 137.86 (1985:M03) and its minimum value was 69.069 (2011:M08). In 2002:M02, the index was at a value of 111 (Graph 1). After that date, the dollar continues to depreciate with respect to the other major currencies and it was 86.2362 (2018:M03). The questions, which arise, here, are: What are the causes of this depreciation? What is the cost and what are the benefits for the U.S.? There are many factors, which have caused the dollar's depreciation. The current account deficit $^{4}{ }^{4}$ the capital account surplus, ${ }^{5}$ the huge national debt, ${ }^{6}$ the inflation ${ }^{7}$ in the country, and the tremendous uncertainty, due to the Middle East crises (Iraq, Afghanistan, Syria, and there are new ones coming, soon $)^{8}$ have created for the U.S. an enormous national debt and for its currency a serious undermining and creeping chronic instability. Also, the low (zero for eight years) interest rate in the U.S. (enormous liquidity) ${ }^{9}$ is depreciating the dollar and caused the

\footnotetext{
2 Some economists say that when U.S. abandoned the exchange of government bonds with gold (\$35/1 oz of Gold), the country technically went bankrupt. Also, some say that the U.S. lost its gold during the period of the Gold Exchange Standard (19441971).

3 USXRI = Trade Weighted Exchange Index: Major Currencies: Index March 1973 = 100. (Source: Economagic.com).

4 The U.S. current account deficit increased to $\$ 128.2$ billion or $2.6 \%$ of GDP in the fourth quarter of 2017 . See, https://tradingeconomics.com/united-states/current-account

5 The U.S. capital account surplus was KA $=-\mathrm{CA}=\$ 128.2$ billion in 2017:Q4.

6 The U.S. ND was $\$ 21.185$ trillion on May 31, 2018.

7 Official inflation rate was, $\pi=2.5 \%$ (April 2018). See, The Wall Street Journal, May 31, 2018. The SGS gives $10 \%$ for the same period. See, http://www.shadowstats.com/alternate_data/inflation-charts
}

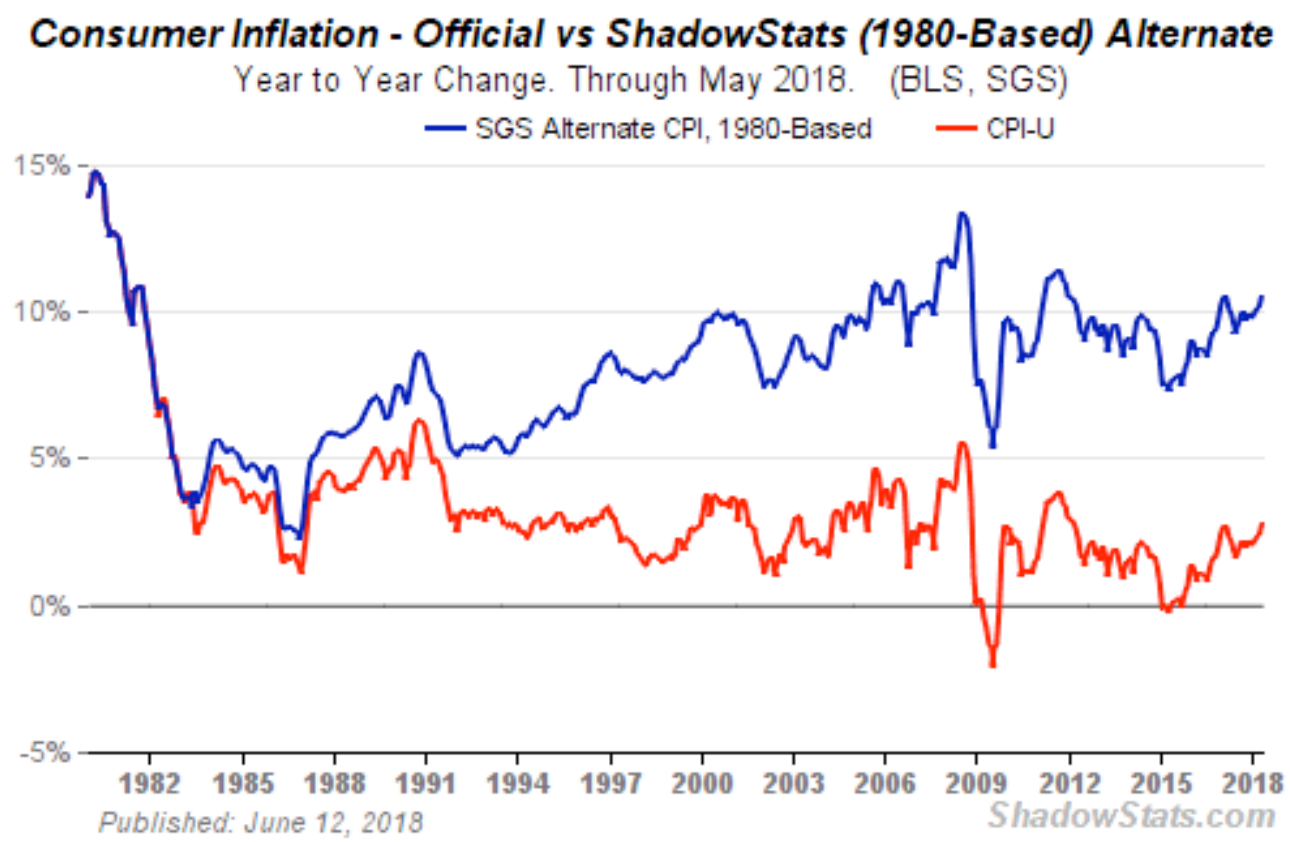

Figure 1: U.S. Inflation Rate (1980-Based)

8 The Muslim Turkey and the three Balkan Muslim nations, created lately by Clinton's war in Yugoslavia, are going to cause serious problems in this region. Like Iran and hopefully not the North Korea, after the Singapore Summit between Trump and Kim. See, "The Singapore Summit between Trump and Kim is finally here (livestream)". https://hotair.com/archives/2018/06/11/singapore-summit-trump-kim-finally/. Also, https://www.npr.org/2018/06/11/618315177/whos-who-at-tuesdays-trump-kim-summit-in-singapore

${ }_{9}^{9}$ When the Fed cuts the interest rate $\left(i_{F F}\right)$, the dollar is depreciated $\left(i_{F F}, U S X R I=+0.455\right)$ and the causality is: $i_{F F} \quad$ USXRI (F-statistic $=3.294^{* *}$ ).

"Well before central banks slashed rates to fight the Great Recession, long-term market rates began slipping. With no reversal in sight, will policymakers lose their main recession-fighting tool?". See, Lukasz A. Drozd, "The Policy Perils of Low Interest 
bubbles in the financial assets. This was followed by the financial crisis (August 2007), which affected the U.S.; and if the Euro-zone had not experienced its unique debt crisis, the dollar could have been worse.

Thus, there is a dollar crisis in the world, due to the enormous level of the U.S. debt: [federal debt $=\$ 21.185$ trillion, social security liability $=\$ 24.9$ trillion, Medicare and Medicaid contingent liabilities $=\$ 56.4$ trillion, state and local governments $=\$ 2.99$ trillion; business sector debt $=\$ 12.778$ trillion, financial sector debt $=\$ 15.247$ trillion, total personal (household) debt $=\$ 14.23$ trillion, financial sector bail-out $=\$ 2.5$ trillion, other debts $=\$ 6.735$ trillion: Total Debt (public: $\$ 114.665$ trillion and private: $\$ 42.3$ trillion) $=\$ 156.965$ trillion]. ${ }^{10}$ The GDP

\section{Graph 1}

\section{The Variability and Depreciation of the U.S. Dollar with Respect to the Major Currencies}

\section{USXRI}

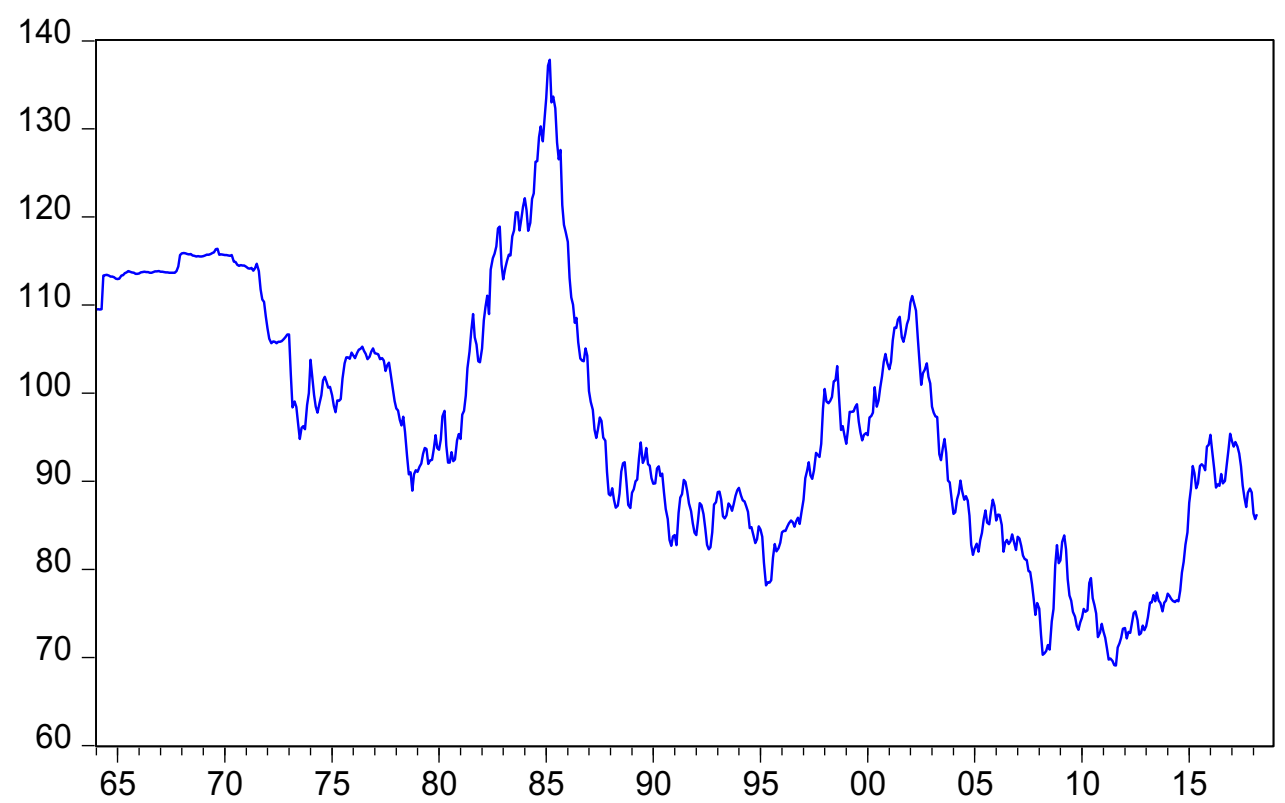

Note: USXRI = Trade Weighted Exchange Index: Major Currencies: Index March $1973=100$. Source: Economagic.com.

(2018:Q1) was $\$ 17.386$ trillion. This puts the total debt at $902.824 \%$ of the GDP. ${ }^{11}$ The Federal Reserve Bank tries to keep the interest rate unnecessarily low to affect positively the financial markets, ${ }^{12}$ but this policy did not help so much the real economy because we had reached a

Rates", Philadelphia Fed, Q1 2018. https://www.phil.frb.org/-/media/research-and-data/publications/economicinsights/2018/q1/eiq118-policy_perils.pdf

10 Source: U.S. National Debt Clock (4/10/2018) and Grandfather Debt Summary (June 2016). http://grandfather-economicreport.com/debt-summary-table.htm

11 Thus, in April 2018, the Social Distress Index (SDI) for the U.S. was:

$S D I=u+\quad+d=3.8 \%+2.5 \%+902.824 \%=909.124 \%$, which show that the country is extremely distressful (risky). See, Kallianiotis (2011, p. 344) for this index. The U.S. needs more than 9 years to pay off its debt, if all the other spending would be zero. Then, it is impossible! See, https://data.bls.gov/timeseries/LNS14000000 . The SGS give an unemployment rate of $21.5 \%$ (April 2018). http://www.shadowstats.com/alternate_data/unemployment-charts

12 The value of our firms depends on: $V=\frac{E B I T(1)}{i}$. Where, $\mathrm{V}=$ market value of the firm, EBIT = earnings before interest and taxes, $\mathrm{T}=$ corporate tax rate, and $\mathrm{i}=$ market rate of interest. 
liquidity trap..$^{13}$ This policy of enormous liquidity caused the bubbles in the financial market and in the housing market and finally, it induced inflation ${ }^{14}$ and contributes to the depreciation of the dollar. The U.S. dollar has declined from its pick point, USXRI=138 (1985:M03) to the lowest USXRI = 69 (2011:M08) until now; lately, it was USXRI = 86 (2018:M03) a decline by more than -50\% (Graph 1). With respect to the euro, the dollar had declined from $0.8530 \$ / €$ (2001:M06) to 1.6001 \$/€ (2008:M04), which was $-87.76 \%$. On April 10, 2018, it was 1.2338 $\$ / €$, a loss of $-44.64 \%$ since its pick value, as Graph 2 shows. Now (May 31, 2018), it is 1.1666 $\$ / €$, a loss of only $-36.76 \%$ since $2001: M 06.15$

The depreciation of a currency means a decline in the purchasing power of the currency, which leads the citizens of the country to a decline in their living standards. The U.S. consumers had lost $88 \%$ of their purchasing power compared to the European ones. An investment in dollars has suffered from this decline. When the dollar is expected to depreciate, investments in the U.S. are falling. The price of importables is going up with the same proportion. All commodities that we import (i.e., oil, coffee, BMW, French wine, etc.) are setting record prices, due to the depreciated dollar. ${ }^{16}$ The OPEC countries watch the deprecation of the dollar, which is the currency that they receive for their sales of oil (except Iran) and they raise its price to keep their revenue constant. The trade deficit ( $\left.\begin{array}{ll}X & M<0\end{array}\right)$ causes the dollar to depreciate, so exports can be stimulated and slightly improve the trade account (price elasticities for exports and imports play a role, here, too $) \cdot{ }^{17}$ As a currency declines in value and interest rate parity ${ }^{18}$ does not hold, investors go to other stronger currencies, i.e., euro, yen, pound, etc. or gold.

\footnotetext{
13 The liquidity trap, in Keynesian Economics, is a situation where monetary policy is unable to stimulate the economy, either through lowering interest rates or increasing the money supply. Liquidity traps typically occur when expectations of adverse events (e.g., deflation, insufficient aggregate demand, low confidence, high risk or civil or international war) make persons with liquid assets unwilling to invest and banks reluctant to lend.

14 The inflation rate in the month of July 2011 was, $\quad=6.22 \%$ per annum. (Economagic.com). In January 2013, it was $1.7 \%$ and in April 2018, the official inflation was given as 2.5\%. But, the Shadow Government Statistics were given an inflation of 10\%. http://www.shadowstats.com/alternate_data/inflation-charts

15 The euro is losing value lately (spring 2018), due to the new political crises in the Euro-zone peripheral nations, especially in Italy and Spain. See, https://www.independent.co.uk/voices/eurozone-madrid-crisis-spain-italy-populist-government-euroeu-a8371726.html

16 This is one reason that the oil from $\$ 28$ per barrel in 1985 had reached on February 27, $2012 \$ 109.14$; an increase by $+289.79 \%$. Its maximum price had been $\$ 144$ per barrel $(+414.29 \%$ raise of price). Lately (June 13,2018 ), it was $\$ 66.36$ per barrel ( $+137 \%$ increase). An abnormal volatility.

17 Treasury Secretary, Tim Geithner, said that "A strong dollar is in the interest of our country, and we'll never embrace a strategy of trying to weaken the currency to gain economic advantage at the expense of our trading partners".

18 Interest Rate Parity (IRP) holds when: $i_{t} \quad i_{t}^{*}=f_{t} \quad s_{t}$, where $i_{t}=$ U.S. short-term interest rate, $i_{t}^{*}=$ foreign short-term interest rate, $f_{t}=$ logarithm of forward exchange rate, $s_{t}=$ logarithm of spot rate.
} 


\section{Graph 2}

The Depreciation of the U.S. Dollar with Respect the Euro 1/EUS

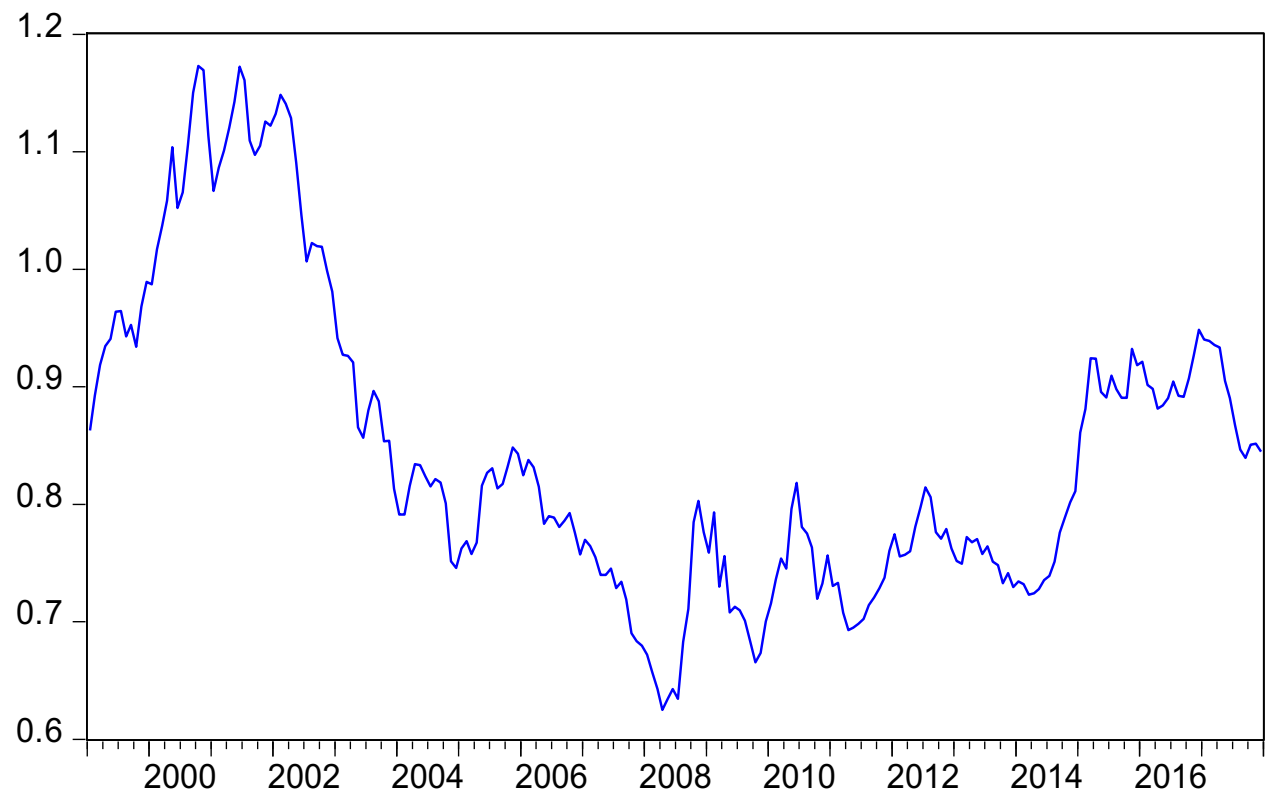

Note: $1 /$ EUS = the exchange rate between dollar and euro $(€ / \$)$.

Source: Economagic.com.

A forecast from the IMF predicted that China's economy will surpass that of the U.S. in five years. ${ }^{19}$ The U.S. Fed, to keep the interest rate close to zero $\left(\bar{i}_{F F}=0.25 \%\right)$, was doing the experiment of "quantitative easing" (printing money). ${ }^{20}$ Then, the U.S. dollar will continue to be at a low level and inflation will rise (April 2018, the true inflation was $\pi=10 \%$ ), ${ }^{21}$ especially, as long as the employment will be improved. At the moment (April 2018), the official unemployment rate was (by construction) low ( $\left.\begin{array}{ll}u & 4.1 \%\end{array}\right) \cdot{ }^{22}$ Europeans and other nations are very critical of this easy money (printing money) policy of the U.S. This is negatively affecting the competitiveness of the foreign countries because their currencies are appreciated, when the dollar is willingly depreciated. The only country that its competitiveness is not affected is China (India follows) with its low cost of production and its controlled economy by the local governments (mayors). ${ }^{23}$

It seems that the IMF is interested in a new world reserve currency. ${ }^{24}$ The U.S. dollar was playing this role since World War II and many resources, like oil, were purchased with the

\footnotetext{
${ }^{19}$ See, Doug McKelway, “Critics Say Fed Policies Devalue the U.S. Dollar”, FoxNews.com, April 26, 2011. This actually happened in December 2017, the Chinese GDP was exceeded the U.S. GDP (\$17.273 trillion).

20 The monetary base (MB) from $\$ 846$ billion in 2007 reached $\$ 2,753$ billion in 2012 , and later became $\$ 4,199$ billion on September 30, $2015(+396.34 \%$ growth or $+49.54 \%$ p. a.). Lately $(5 / 23 / 2018)$, it was $\$ 3,662$ billion. See,

https://fred.stlouisfed.org/series/BASE/

${ }^{21}$ See, http://www.shadowstats.com/alternate_data/inflation-charts

22 But, the unofficial one was $21.7 \%$. See, http://www.shadowstats.com/alternate_data/unemployment-charts

23 This is a Chinese state-run capitalism. We see these philosophies in Europe and in U.S., lately, spread by the liberals (globalists). For example, the Frankfurt School in Germany, the Round Table groups, the Council on Foreign Relations, and the Trilateral Commission. All these organizations have aligned the U.S. and the EU with their Marxist vision of state control and management of the economy. See, McGuire, Paul and Troy Anderson (2018), Trumpocalypse, New York: Faith Words, Hachette Book Group.

${ }^{24}$ As it was reported, extensively, by the media, in February 2011. See,

http://money.cnn.com/2011/02/10/markets/dollar/index.htm. See also,
} 
dollar (petro-dollars). The U.S. was increasing its debt and countries with a surplus (Germany, China, Japan, OPEC nations, etc.) were financing the U.S. debts. Since the 1980s with all these deregulations in the U.S. financial market, the frauds in investment banks, ${ }^{25}$ the corruption, the housing bubble, and the financial crisis of 2007-2013, the U.S. dollar continues to depreciate. The SDR (Special Drawing Rights) and the euro are competing with the dollar for their share as world reserve currencies. ${ }^{26}$ The G-20, the IMF, the World Bank, and the Bank of International Settlement are supporting the role of SDR. The U.S. has lost most of its manufacturing infrastructure the last 30 years ${ }^{27}$ and it is importing much of the natural resources, oil, food, etc. If SDR or the euro will become world's reserves, the demand for the dollar will fall and the dollar will depreciate further. Thus, it will be very costly for Americans to pay for their importables; their purchasing power and their domestic wealth will be restrained even more after the latest financial crisis. Already, there are about 50 million Americans, who receive federal assistance (Medicare, social security, disability, and unemployment). ${ }^{28}$ As the dollar will be depreciated, there will be higher cost of imports, more unemployment, lower income, confinement of wealth, more home foreclosures, and more bankruptcies, if manufacture does not return back to the U.S. because so far consumption (absorption) exceeds production.

When income and wealth is falling in a country, famine starts and when people are hungry, they will go to the streets demonstrating against their country, their government, and their financial crisis, as it is going on in Europe the last nine years. During the latest financial crisis, we saw many peaceful demonstrations in New York City (Wall Street), in Boston, Washington, Los Angeles, and ten other big cities in the U.S. ${ }^{29}$ The U.S. supports too many global military goals, which cause tremendous cost (monetary ones in trillions of dollars and in human lives) for the country and unfortunately, Cold War with Russia is continued. ${ }^{30}$ China, with a complete

http://theeconomiccollapseblog.com/archives/shocking-new-imf-report-the-u-s-dollar-needs-to-be-replaced-as-the-worldreserve-currency-and-that-sdrs-could-constitute-an-embryo-of-global-currency. Even Chinese yuan became part of the SDR in October 2016. See, http://fortune.com/2016/10/02/china-yuan-imf-currencies/. Also, http://www.imf.org/external/np/fin/data/rms_sdrv.aspx

25 The SEC charged a former Goldman Sachs employee with tipping off his father in the first insider-trading case related to the market in ETFs. [A security that tracks an index, a commodity or a basket of assets like an index fund, but trades like a stock on an exchange. ETFs experience price changes throughout the day as they are bought and sold.] See, The Wall Street Journal, September 22, 2011, pp. A1 and C1. Kweku Adoboli, the UBS AG (UBSN) trader charged with fraud and false accounting that may have resulted in a $\$ 2.3$ billion loss; he said through his lawyer that he was "sorry beyond words" after facing an additional fraud charge at a court hearing on September 22, 2011. (Bloomberg.com, 9/22/2011).

${ }^{26}$ In 2017, the percentage of dollars in the world market was: $62.70 \%$, euros: $20.15 \%$, and SDRs: SDR 204.2 billion (\$291 billion) with September 2017. See,

http://www.imf.org/en/About/Factsheets/Sheets/2016/08/01/14/51/Special-Drawing-Right-SDR Composition of Official Exchange Reserves).

(IMF: Currency

27 President Donald Trump tries very hard to bring manufacturing back to the U.S., but there is too much opposition from the "establishment", the liberals, and the swamp of Washington, which ravage the country and its poor European immigrants since

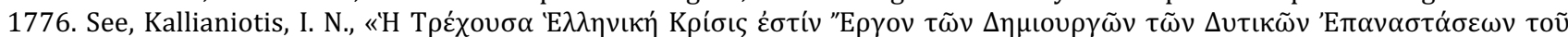

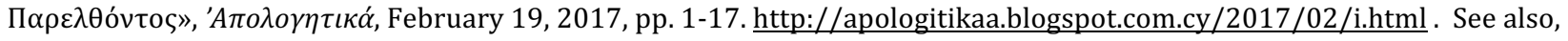
https://www.washingtontimes.com/news/2017/feb/23/donald-trump-tells-business-ceos-he-wants-them-bri/. Also, http://knowledge.wharton.upenn.edu/article/can-trump-anyone-bring-back-american-manufacturing/ . Further,

https://ustr.gov/issue-areas/industry-manufacturing/industrial-tariffs . Furthermore,

http://www.tulsaworld.com/business/u-s-proposes-percent-tariffs-on-billion-in-chinese-imports/article_c1d1cba6-eb62$\underline{575 \mathrm{e}-\mathrm{b} 02 \mathrm{c}-\mathrm{fc} 97 \mathrm{dc} 444 \mathrm{ac} 4 . \mathrm{html}}$

28 See, https://www.thenewamerican.com/economy/item/18977-more-than-1-3-of-americans-in-households-receivingfederal-welfare . Also, https://www.washingtonpost.com/news/wonk/wp/2012/09/18/who-receives-benefits-from-thefederal-government-in-six-charts/?noredirect=on\&utm_term $=. c 483187 \mathrm{a} 83 \mathrm{f} 8$

Further, https://www.census.gov/newsroom/press-releases/2015/cb15-97.html. The distribution of income and wealth is completely unfair. See, https://whorulesamerica.ucsc.edu/power/wealth.html . In addition, http://fortune.com/2014/10/31/inequalitywealth-income-us/ and http://apps.urban.org/features/wealth-inequality-charts/

29 TV News CNN, October 9, 2011.

30 The West must understand that Russians are not enemies of the Americans and Europeans, but the best people on earth, due to their European culture, Orthodox faith, and knowledge of Truth. The people in the West have to start learning history and 
different economic structure and culture from the West, has become a major rival, a future adversary for the U.S., and a serious economic competitor of EU and U.S.A. The free trade agreement (membership in WTO) among these entities will result in economic decay of the lasts.

The U.S. economy was depending on credit to invest, consume, and grow; but, this advantage turned to a big disadvantage, an unmanageable debt. The U.S. market oriented system from capitalism became debtism, which is the objective of the dangerous bankers. ${ }^{31}$ This economic expansion, fueled by debt-based capital markets, ${ }^{32}$ gave only a temporary advantage of the West (capitalism) toward the East (communism). Now, with the latest financial crisis and the debt crises, the West seems to be worse off than the East because it went a step forward. It altered capitalism to a new system, the globalism (global debtism, which will progressed to global confiscation of private wealth) and its first social cost is obvious since 2007. The creditdriven expansion will be restricted in the future and the debt-driven contraction will take over. The two large U.S. bubbles (dot.com and housing) have caused serious problems to the "laissez-faire, laissez-passer" economic system. ${ }^{33}$ This system recently caused a global contraction and serious social welfare problems (from bankruptcies to suicides). The

not only the anti-Russian propaganda, which is spread by the controlled media, the "fake news". The globalist David Rockefeller was thanking the controlled media because they obey to the dark powers orders to conceal their objective, the globalization (global slavery): "We are grateful to the Washington Post, the New York Times, Time Magazine and other great publications whose directors have attended our meetings and respected their promises of discretion for almost forty years. It would have been impossible for us to develop our plan for the world if we had been subjected to the lights of publicity during those years. But, the world is more sophisticated and prepared to march towards a world government. The supranational sovereignty of an intellectual elite and world bankers is surely preferable to the national auto-determination practiced in past centuries." (David Rockefeller, Speaking at the June, 1991 Bilderberger meeting in Baden, Germany. A meeting also attended by then-Governor Bill Clinton and by Dan Quayle.) See, http://www.rense.com/general17/quote.htm Also, John Swinton, the former Chief of Staff at the New York Times was asked to give a toast before the prestigious New York Press Club in 1953. He made this candid confession [it's worth noting that Swinton was called "The Dean of His Profession" by other newsmen, who admired him greatly]. "There is no such thing, at this date of the world's history, as an independent press. You know it and I know it. There is not one of you who dares to write your honest opinions, and if you did, you know beforehand that it would never appear in print. I am paid weekly for keeping my honest opinions out of the paper I am connected with. Others of you are paid similar salaries for similar things, and any of you who would be so foolish as to write honest opinions would be out on the streets looking for another job. If I allowed my honest opinions to appear in one issue of my paper, before twenty-four hours my occupation would be gone. The business of the journalist is to destroy the truth; to lie outright; to pervert; to vilify; to fawn at the feet of mammon, and to sell the country for his daily bread. You know it and I know it and what folly is this toasting an independent press. We are the tools and vassals of the rich men [the dark powers] behind the scenes. We are the jumping jacks, they pull the strings and we dance. Our talents, our possibilities and our lives are all the property of other men. We are intellectual prostitutes." One current proof of all the above quotes is how the world media were facing the campaign and the debates for the U.S. election in 2016; all these controlled and corrupted media (fake news) are against Donald Trump because he is not "politically correct", he is saying the truth, he is a Christian, against abortion, and anti-globalist, and the establishment (the professional politicians controlled by lobbyists and the dark powers) does not want to hear it. But God has His own plans for His creation. At the G7 Summit in Canada, President Trump said that "we must accept Russia back and reinstate G8". (FoX News, June 9, 2018). Liberals, globalists, and the establishment are against this view because they have established the Cold War with Russia and their diseased plans will never change.

${ }^{31}$ And the control by the bankers Fed, seeks to loosen Volcker Rule for banks. See, https://www.wsj.com/articles/fed-floatschanges-to-volcker-rule-on-big-bank-trading-restrictions-1527705603

32 Capital structure theories in 1950s and 1960s were recommending $100 \%$ debt as the optimal amount of debt because the interest on debt is tax deductible (paid by the tax payers and the national debt became unmerciful for the future of the country), which is unethical for the poor citizens. Corporations have to start paying taxes because they are receiving everything from the country (its citizens), like, the economic environment, the financial markets, the legal system, the institutions, the labor used for their production, the purchasing of their products and services, etc. President Obama offered to reduce corporate tax rate to $28 \%$. See The New York Times, February 22, 2012.

http://www.nytimes.com/2012/02/22/business/economy/obama-offers-to-cut-corporate-tax-rate-to-

28.html?pagewanted=all. President Obama wanted to increase the taxes for people, who have an income above $\$ 250,000$. But the Republicans disagreed; they wanted all taxes to go up, as it happened in January 2013. See, The Washington Post, November 13, 2012. http://www.washingtonpost.com/business/economy/obama-to-open-fiscal-talks-with-plan-to-raisetaxes-on-wealthy/2012/11/13/9984cd78-2dc1-11e2-89d4-040c9330702a story.html .

Recently, President Trump reduced corporate tax rates from $35 \%$ to $21 \%$. Actually, corporations will not pay any taxes. See, http://www.businessinsider.com/how-trump-tax-reform-will-affect-you-according-to-financial-advisor-2018-1

33 See, Kallianiotis and Harris (2010).

Copyright (C) Society for Science and Education, United Kingdom 
deregulations and the expansionary monetary policy for ten years, have prepared a new bubble, which waits for the appropriate time to burst.

Global demand is falling as credit contracts and employment and income are falling, too. The U.S., as the world's largest debtor, might have difficulties paying what it owes in the future, except by rolling its debt forward and borrowing more. ${ }^{34}$ Today, the debt is everyone's problem because it has reached an un-payable level. A default by the U.S. will have global consequences, especially in China and the other large creditors of the U.S. The amount of outstanding U.S. debt (public and private) has reached a level that can never be paid off. ${ }^{35}$ Historically, inflation destroys the value of money. ${ }^{36}$ Debts are paid back with inflated dollars, a process, which benefits the debtor and injures the creditor (U.S. usually inflates its way out of debt by printing what it owes). Depreciation of the dollar is another option to benefit borrowers at the expense of lenders. Taxation is a different option that has similar results as the two previous ones, but already the U.S. middle-class is paying very high taxes. Corporations, in the U.S. and all over the world, do not pay taxes. The tax avoidance, taxevasion, and tax-inversion from the MNCs (U.S. companies have stashed \$2.1 trillion overseas to avoid taxes) ${ }^{37}$ have become scientific.

Actually, corporations and wealthy people are paying relatively less taxes compared to the middle class, which is unfair and unethical and the tax evasion is very high, too. This illegal capital fly is a large proportion of deposits in offshore centers and tax havens. ${ }^{38}$ Also, GE paid

\begin{abstract}
34 "Ponzi-financing" according to Hyman Minsky. See, http://wfhummel.cnchost.com/minsky.html
35 . "...the United Sates government and its agencies have, by far, the largest pile-up of interest-bearing debts (\$15.6 trillion), the largest accumulation of unsecured obligations (over $\$ 60$ trillion), the largest yearly deficit ( $\$ 1.6$ trillion), and the greatest indebtedness to the rest of the world (\$4.8 trillion)." See, Martin D. Weiss, www.moneyandmarkets.com. These numbers are much higher by now, as it was mentioned above (p. 4). See, for the U.S.

http://www.usdebtclock.org/ and the world, http://www.usdebtclock.org/world-debt-clock.html

36 Many hyperinflations around the world, like the German (1923): 3,250,000\%, the Greek (1944): 8,500,000,000\%, and the Hungarian (1946): 13,000,000,000,000,000\%. The U.S during the Revolutionary War, when the Continental Congress authorized the printing of paper currency called continental currency. The monthly inflation rate reached a peak of $47 \%$ in November 1779. These notes depreciated rapidly, giving rise to the expression "not worth a continental." A second close encounter occurred during the U.S. Civil War, between January 1861 and April 1865, the Lerner Commodity Price Index of leading cities in the eastern Confederacy states increased from 100 to over 9,000. As the Civil War dragged on, the Confederate dollar had less and less value, until it was almost worthless by the last few months of the war. Similarly, the Union government inflated its greenbacks, with the monthly rate peaking at $40 \%$ in March $1864 . \quad$ See,
\end{abstract} http://www.jewishvirtuallibrary.org/alexander-hamilton

37 The Treasury tries to tighten tax rules to deter U.S. firms from moving their headquarters overseas and slow a wave of socalled corporate inversions that reduce federal government revenues. (The Wall Street Journal, September 23, 2014, pp. A1 and A2). See also, Pfizer's audacity. Chief Executive Officer Ian Read said: "I see no reason why we wouldn't be able to do an inversion." http://www.bloomberg.com/news/2014-10-28/pfizer-lowers-full-year-sales-guidance-on-competition.html . See Pfizer's taxes:

http://www.americansfortaxfairness.org/files/Pfizer-Fact-Sheet-FINAL.pdf . Also, Gilead Sciences Inc., whose \$1,000-a-pill hepatitis $C$ treatment is one of the world's most expensive drugs, is avoiding billions of dollars in U.S. taxes by booking profits overseas. The company reported foreign income before taxes of $\$ 8.2$ billion for 2014 , earning more in non-U.S. profits than it recorded in non-U.S. sales. Gilead is shifting valuable intellectual property to low-tax countries and paying about 5 percent in taxes on its foreign income. Gilead's disclosure is the latest example of tax planning by U.S.-based multinational corporations, which hold about $\$ 2$ trillion in stockpiled profits outside the country that haven't been taxed by the U.S. The federal government loses as much as $\$ 100$ billion in revenue annually because of such international tax planning, according to estimates cited in a Congressional Research Service study. See, http://www.bloomberg.com/news/articles/2015-0226/gilead-avoids-billions-in-u-s-taxes-on-its-1-000-a-pill-drug. Microsoft Corp., Apple Inc., Google Inc. and five other tech firms account for more than a fifth of the $\$ 2.10$ trillion in profits that U.S. companies are holding overseas, according to a Bloomberg News review of the securities filings of 304 corporations. The total amount held outside the U.S. by the companies was up 8 percent from the previous year, though 58 companies reported smaller stockpiles. See,

http://www.bloomberg.com/news/articles/2015-03-04/u-s-companies-are-stashing-2-1-trillion-overseas-to-avoid-taxes

These business practices are completely unethical and against not only the U.S. citizens, but against themselves, too. The national debt might become unsustainable.

${ }^{38} \mathrm{See}, \mathrm{http}$ ///www.boston.com/business/globe/articles/2004/04/11/most_us_firms_paid_no_income_taxes_in_90s/. 
no taxes and Goldman Sachs paid only $\$ 14$ million in 2010. The GAO reported in 2008 that "two out of every three United States corporations paid no federal income taxes from 1998 through 2005". Companies have become all too astute at paying for loopholes, which allow them to shift profits abroad or move their gains (on paper) to foreign low-tax/no-tax nations. As the data shows, the change in corporate taxes — not merely rates, but what they actually paid — over the past half century are astounding. ${ }^{39}$

Also, inflation, through monetary expansion, could raise aggregate U.S. debt and prices further. With the current enormous money supply and with a very low interest rate, we reached a liquidity trap and this policy failed to promote growth. Europe is in trouble, due to lack of liquidity (the ECB's overnight deposit rate was 1\%; then, it fell to $0.75 \%$ and at the end to $0.00 \%) .^{40}$ Lending has declined drastically in the U.S. and even more in Europe. The question is now: from where will the expected stimulus come? Of course, if this U.S. monetary expansion had been used by the economy, we could have experienced hyperinflation in the U.S. Thus, it is safe for the economy, at the moment, because the high risk, the low income, and the high unemployment have made banks reluctant to lend and people unwilling to borrow. The U.S. has experienced high rates of inflation ${ }^{41}$ in the past, even though the number one objective of the Fed is "price stability" ( $e \quad 0$ or a desired inflation, ${ }^{*} 2 \%$ ). The monetary expansion the last ten years has far exceeded any previous ones. ${ }^{42}$ Then, what follows, when the unemployment will fall, it might be a high inflation. This liquidity and uncertainty in the market has increased the price of gold (Graph 3$)^{43}$ and silver (another big bubble in precious metals). ${ }^{44}$ Furthermore, depreciation of the dollar helps partially the U.S., but not the creditors of the country because their return is falling from their U.S. investments (translation exposure). China has linked its currency to the U.S. dollar, so with any depreciation of the dollar, the yuan is also declining in value and China becomes the major beneficiary by increasing its exports. Graph 4 shows the yuan/dollar exchange rate. Thus, the peg of the Chinese yuan to the U.S. dollar prevents the U.S. from altering its trade deficit by currency devaluation, but it helps the U.S. relative to the other countries (i.e., the Euro-zone), where their currencies are appreciated. In the 1980s, the U.S. needed Japanese savings to finance Reagan's multi-trillion dollar debtbased military buildup (the famous "star war"). If Japanese rates were raised, Japanese savings would stay at home, but Japanese rates were kept low (with the "help" from the U.S.). These low interest rates and high earnings of Japanese firms, due to their exports, ignited a speculative frenzy in their stock markets causing the then largest stock market bubble in history. In 1990, the bubble collapsed and Japan fell into a deflationary trap, from which it has never fully emerged.

\footnotetext{
39 (1) Corporate taxes as a percentage of Federal Revenue were; in 1955: 27.3\% and in 2010: 8.9\%. (2) Corporate taxes as a percentage of GDP; in 1955: 4.3\% and in 2010: 1.3\%. (3) Individual income/payrolls as a percentage of Federal Revenue; in 1955: 58.0\% and in 2010: 81.5\%. See, http://www.ritholtz.com/blog/2011/04/corporate-tax-rates-then-and-now/

40 See, https://www.ecb.europa.eu/stats/policy_and_exchange_rates/key_ecb_interest_rates/html/index.en.html

41 From 1926-2014, the ${ }^{-}=3 \%$ and $= \pm 4.1 \%$. Source: Modified from Stocks, Bills, and Inflation: 2015 Yearbook, annual updates work by Roger G. Ibbotson and Rex A. Sinquefield (Chicago: Morningstar).

42 The Monetary Base (seasonally adjusted) in billions of dollars was: In 2000: $\$ 613.869,2001$ : $\$ 668.020,2002: \$ 716.722$, 2003: \$754.871, 2004: \$789.177, 2005: \$814.831, 2006: \$836.193, 2007: \$846.212, 2008: \$1,690.796, 2009: \$1,994.401, 2010: $\$ 1,982.737,2011: \$ 2,559.195,2012: \$ 2,633.407,2013: \$ 3,715.825,2014: \$ 3,994.596,2015: \$ 3,822.108,2016: \$ 3,520.479$, 2017: \$3,847.715, and 2018:M03: \$3,771.299 billion. Source: Federal Reserve Bank of St. Louis. See, http://research.stlouisfed.org/fred2/data/BASE.txt

43 See, http://www.macrotrends.net/1333/historical-gold-prices-100-year-chart

44 The price of gold was; 2000: \$280.10/1 oz Gold, 2001: \$272.22, 2002: \$311.33, 2003: \$364.80, 2004: \$410.52, 2005: $\$ 446.00,2006$ : \$647.10, 2007: \$842.80, 2008: \$841.70, 2009: 1,084.70, 2010: \$1,405.60, 8/22/2011: \$1,892.60, 2/27/2012: $\$ 1,774.40$, on $2 / 19 / 2013$ it was $\$ 1,604.10$ /oz. It fell in December 2015 to $\$ 1,128.06$, and on April 12,2018 it was $\$ 1,335.23 /$ oz of Gold. (Bloomberg.com).
} 
Graph 3

The Depreciation of the U.S. Dollar with Respect the Gold

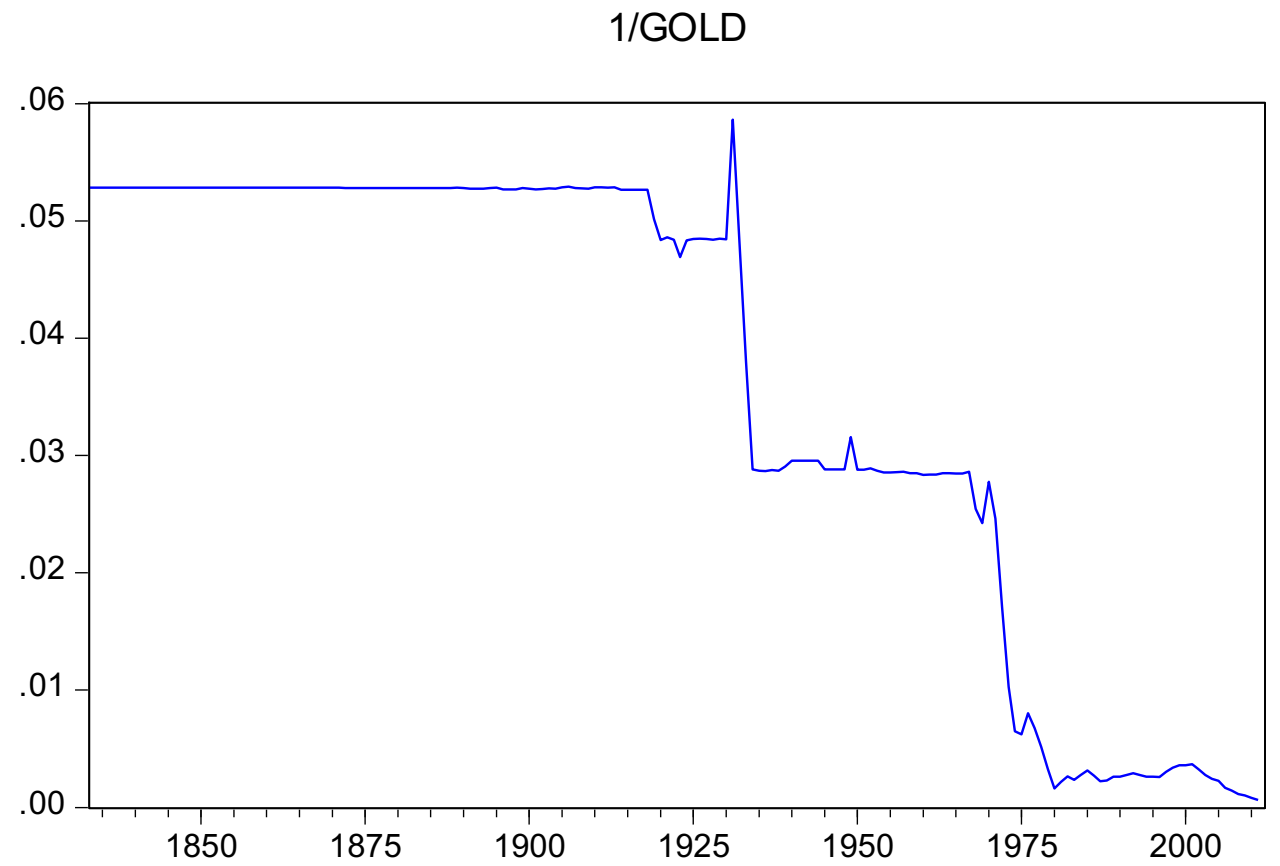

Note: $1 /$ GOLD=the value of U.S. dollar with respect the price of gold. (troy ounces of gold/\$).

Source: Historical Gold Prices-1833 to Present.

http://www.nma.org/pdf/gold/his_gold_prices.pdf.

Today, the economic power has shifted to China from Japan. The U.S. imports from China are enormous $^{45}$ and it is financing its debts and deficits with Chinese capital. ${ }^{46}$ Thus, the U.S. dominance is being challenged by China. If China will reduce its holdings of U.S. debt, it will affect the U.S. deficits, interest rates, and the value of the dollar. A depreciation of the U.S. dollar by $30 \%$ would impact the debt held by foreigners; their losses would be significant. ${ }^{47}$ Of course, after the above economic impacts, geopolitical considerations are taking place. Expenditures are rising in the U.S., production is falling, and the need to borrow is increasing. Then, the total U.S. debt (public and private) would prove difficult of even being repaid. The future of all nations might be complicated with all these absurd decisions ("irrational exuberance") of the last 30 years. In 1973, when gold was taken out as a monetary asset,

\footnotetext{
45 Trade deficit with China: in 2010 , it was $\$ 273.1$ billion, in 2011 , it was $\$ 295.5$ billion and in 2017 , it was $\$ 375.2$ billion; in 1985 it was only $\$ 6$ million. See, http://www.census.gov/foreign-trade/balance/c5700.html

46 With March 2011, Chinese were holding $\$ 29.583$ billion of U.S. L-T securities. See also, "U.S. net long-term capital inflows rises to $\$ 30.6$ billion": Foreigners increased purchases of long-dated US securities in April for the first time in five months, while China raised its holdings of US government debt. The United States attracted a net long-term capital inflow of $\$ 30.6$ billion in April, an increase from $\$ 24$ billion the prior month. Including short-dated assets such as Treasury bills, foreigners bought a net of $\$ 68.2$ billion. That was down from an upwardly revised $\$ 127.1$ billion inflow in March. Net overseas buying of U.S. Treasury debt fell by $\$ 3.4$ billion to $\$ 23.3$ billion, a fifth consecutive monthly decline. But net foreign purchases of U.S. equities rose. China, the largest foreign U.S. creditor, increased its overall Treasury holdings by $\$ 7.6$ billion to $\$ 1.153$ trillion. (Reuters, June 15, 2011). With December 2017, China was holding $\$ 1,184.9$ billion and Japan $\$ 1,061.5$ billion U.S. Treasury securities. See, https://www.statista.com/statistics/246420/major-foreign-holders-of-us-treasury-debt/

See,http://www.khaleejtimes.com/biz/inside.asp?xfile=/data/economicindicator/2011/June/economicindicator_June18.xml \&section=economicindicator

47 China in 2012 owned $\$ 3,341$ billion of foreign exchange reserves and $\$ 1,584$ billion of U.S. public and private debt in U.S. dollar denominated securities; and a depreciation of the dollar by $30 \%$, it will cost China $\$ 475.2$ billion in losses of its investment. See, https://fas.org/sgp/crs/row/RL34314.pdf
} 
balance sheets of every central bank of the world suffered, as their dollar-denominated assets sank in value, in terms of dollar. 48

\author{
Graph 4 \\ The U.S. Dollar-Yuan Exchange Rate (yuan/\$)
}

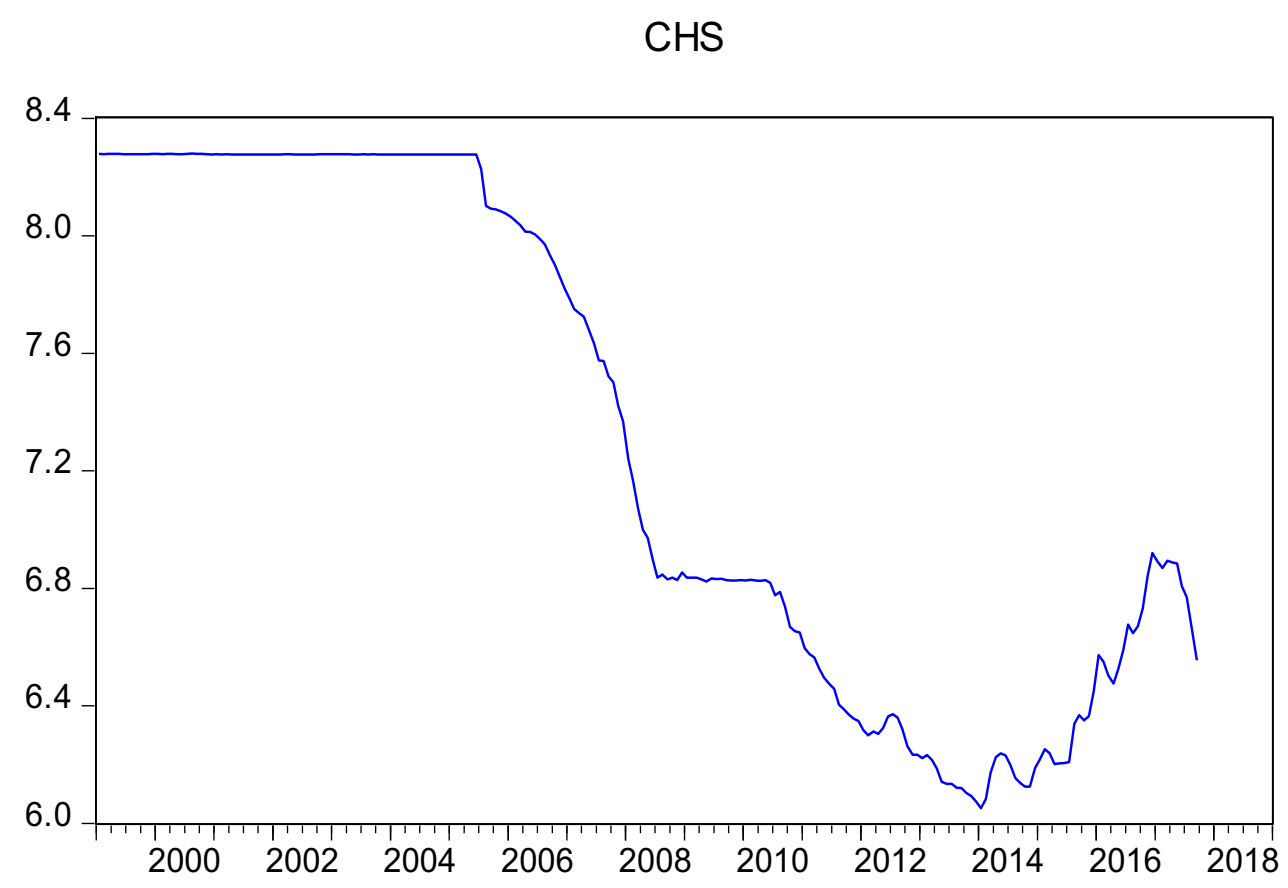

Note: CHS= Chinese yuan/U.S. dollar exchange rate.

Source: Economagic.com

Unfortunately, lately, spreads on sovereign debt are rising and credit default swaps (CDS) reflect the higher premiums being charged to protect against default. Investors compare risk (

$\left.{ }_{D}\right)$ to reward $\left[E\left(R_{D}\right)\right]$ and try to maximize the reward to variability ratio of their bonds' investments $\left(R V=\frac{\left[E\left(R_{D}\right) R_{R F}\right]}{D}\right)$ in regards to debt; when the reward is believed to compensate for the risk (max RV), the bond is bought and the bet is placed. Some countries were paying $48.60 \%$ interest rate, due to high austerity measures that have increased the probability of bankruptcy, as it happened, lately, with Greece ${ }^{49}$ and other Euro-zone countries (PIIGS nations). ${ }^{50}$

\title{
TRADE POLICIES AND SOCIAL WELFARE
}

An (international) trade policy is a governmental policy governing economic transactions across international borders. ${ }^{51}$ This covers tariffs, ${ }^{52}$ trade subsidies, ${ }^{53}$ import quotas, ${ }^{54}$

\footnotetext{
48 Some economists are saying that the U.S. technically defaulted in 1973 , when it officially reneged on its gold obligations under Bretton-Woods, leaving other nations holding U.S. paper dollars that could no longer be converted to gold.

49 See, https://tradingeconomics.com/greece/government-bond-yield

50 They are Portugal, Ireland, Italy, Greece, and Cyprus.

51 See, https://en.wikipedia.org/wiki/International_trade

52 See, https://en.wikipedia.org/wiki/Tariff . Also, Heller (1973, pp. 163-181).

53 See, https://en.wikipedia.org/wiki/Subsidy. Also, Williamson (1983).

${ }^{54}$ An import quota is a type of trade restriction that sets a physical limit on the quantity of a good that can be imported into a country in a given period of time. Quotas, like other trade restrictions, are typically used to benefit the producers of a good in that economy. See, O’Sullivan, Arthur and Sheffrin, Steven M. (2003), Economics: Principles in Action. Pearson Prentice Hall.
} 
voluntary export restrictions, ${ }^{55}$ restrictions on the establishment of foreign-owned businesses, regulation of trade in services, and other barriers to international trade. ${ }^{56}$

Trade policy defines standards, goals, rules and regulations that pertain to trade relations between countries. ${ }^{57}$ These policies are specific to each country and are formulated by its public officials. Their aim is to boost the nation's international trade, improve employment in the country, bring businesses back to the country, and maximize the social welfare of its citizens. A country's trade policy includes taxes imposed on import, inspection regulations, and tariffs and quotas. A trade policy generally focuses on the following specifications in terms of international trade:

(1) Tariffs: Every country has the right to impose taxes on imported goods. Some nations levy heavy tariffs on imported goods to protect their local industries, create jobs by increasing domestic production. A tariff is increasing the price of importables and makes the domestic economy more competitive. [eqs. (6) and (6')]. High import taxes inflate the prices of imported goods in local markets, ensuring that local products are more sought after. But these tariffs have increased employment and income in the domestic economy, so consumers can pay for these higher prices of their domestic products, which are also of better quality. The U.S. has trade deficits with Canada of $\$ 17.58$ billion, with EU $\$ 151.42$ billion, and with Mexico \$71.06 billion. ${ }^{58}$

(2) Trade barriers: They are state-imposed restrictions on trading a particular product or with a specific nation. Some of the most common forms of trade barriers are tariffs, duties, subsidies, embargoes and quotas. For countries that their cost of production is $1 / 40$ of the U.S. cost (China, India, etc.), the U.S. has to put restrictions on trade, otherwise it cannot compete with them. A lack of competitiveness destroys the domestic economy and affects negatively the social welfare of the country.

(3) Safety: This determinant ensures that only high-quality products are imported in the country. Public officials can lay down inspection regulations to ensure that the imported product conform to the set safety and quality standards. In many developing countries the

\footnotetext{
55 A voluntary export restraint (VER) or voluntary export restriction is a government-imposed limit on the quantity of some category of goods that can be exported to a specified country during a specified period of time. They are sometimes referred to as "Export Visas". Typically VERs arise when industries seek protection from competing imports from particular countries. VERs are then offered by the exporting country to appease the importing country and deter it from imposing explicit (and less flexible) trade barriers. VERs have been used since the 1930s at least, and have been applied to products ranging from textiles and footwear to steel, machine tools and automobiles. They became a popular form of protection during the 1980s; they did not violate countries' agreements under the General Agreement on Tariffs and Trade (GATT) in force. As a result of the Uruguay round of the GATT, completed in 1994, World Trade Organization (WTO) members agreed not to implement any new VERs, and to phase out any existing ones over a four-year period, with exceptions grantable for one sector in each importing country. Some examples of VERs occurred with automobile exports from Japan in the early 1980s and with textile exports in the 1950 s and 1960 s.

56 These are sometimes agreed by treaty within a customs union. In the case of the European Union, trade (commercial) policy has been governed in common since the EU was created in 1957. A common commercial policy is also an aim of Mercosur. Mercosur is a South American trade bloc established by the Treaty of Asunción in 1991 and the Protocol of Ouro Preto in 1994. Its full members are Argentina, Brazil, Paraguay, and Uruguay. Venezuela is a full member but has been suspended since December 1, 2016. Associate countries are Bolivia, Chile, Peru, Colombia, Ecuador, and Suriname. See, https://en.wikipedia.org/wiki/Suriname. Also, observer countries are New Zealand and Mexico.

57 See, https://2012books.lardbucket.org/books/policy-and-theory-of-international-trade/s11-domestic-policies-andinternat.html

58 See, William Mauldin, “U.S. Levies Raise Fear of Trade War”, The Wall Street Journal, June 1, 2018, pp. A1, A2, and B9. See also, http://www.kusi.com/trump-barrels-into-g-7-summit-ready-to-fight-us-allies/ . In addition, https://dailymarkhor.com/world-leaders-managed-to-find-an-agreement-at-the-g7-then-trump-tweeted-by-buzzfeed/
} 
quality, the sanitation, and the health standard are very low or do not exist; then, restrictions are absolutely necessary. ${ }^{59}$

Trade policies can assume varying dimensions and scope depending on the number of parties involved in the policy. Every country formulates its national trade policy to safeguard the best interest of its trade and citizens. ${ }^{60}$ This policy is always in consonance with the national domestic and foreign policy. Also, bilateral trade policy is formed between two nations to regulate the trade and business relations with each other. The national trade policies of both the nations and their negotiations under the trade agreement are considered while formulating bilateral trade policy. These policies can apply among Western economies, which are very similar, but within different economies cannot be enforced because of the enormous wage differential between the countries.

International economic organizations, such as the Organization for Economic Co-operation and Development (OECD), the World Trade Organization (WTO) and the International Monetary Fund (IMF), have different views on international trade policy, which is very suspicious. They care for the increase of international trade and not for the welfare of specific nations. Their policy is globalism as they carry out the globalists' objectives; one world, no sovereign nations, no national welfare, and global control. These policies are against the interests of both developed and developing nations, thus, they are rejectable; the first group of nations lose their industries, production, income and welfare and the second ones are exploited by the MNCs and suffered with child labor, pollution, and unfairness. The best example is the Doha Development Agenda, which was formulated by the WT0.61

As open market economy has caused enormous problems in most of the developed countries, international economic organizations, as non-national and strange agents, support free trade policies; but developing and developed nations prefer partially-shielded trade practices to protect their local industries and their citizens' wellbeing. Today's era of unrestrained globalization, which is the only objective of the dark powers, depends on sound trade policies to reflect market changes, establish free trade practices and expand the possibilities for booming international trade, by ignoring the effects and the cost to the different nations, as it happened with the EU member-nations.

The social welfare function $(\mathrm{W})$ can be written as, $\max W=f\left(u_{1}, u_{2}, u_{3}, \ldots, u_{N}\right)$

subject to constraints (Factor endowments, L, K, T, E; Technology; Tastes)

\footnotetext{
${ }^{59}$ Recently, the Greek customs found Turkish products going to Europe that were completely unsaved, contaminated with pesticides, dangerous chemicals, and other unhealthy substances. Some developing countries do not afford to buy fertilizers and they use raw sewage to fertilize their gardens with vegetables. Other examples are the poultry and mad-cow diseases in the past. Lately, effects of E.coli outbreak in lettuce ripple through U.S. food-supply chain. Tainted lettuce is off the market, officials say, but prices have dropped by more than half and some growers have left acres of romaine to rot. See, https://www.wsj.com/articles/effects-of-e-coli-outbreak-in-lettuce-ripple-through-u-s-food-supply-chain-1527681604, May 30, 2018. Other cases of unsaved products: "Flu Shots Are FILLED With Heavy Metals And Toxins". See, https://www.naturalnews.com/051485_flu_shot_dirty_syringe_New_Jersey_nurse.html . Further, https://www.naturalnews.com/045418_flu_shots_influenza_vaccines_mercury.html. In addition, http://themillenniumreport.com/2017/09/proof-flu-shots-are-the-greatest-medical-fraud-in-the-history-of-the-world/ 60 But, retaliations and other problems can appeared, too. See, U.S. Tariffs Prompt Anger, Retaliation from Trade Allies: Mexico strikes back with plan to target U.S. steel products, fruits and pork chops, Wall Street Journal, May 31, 2018. https://www.wsj.com/articles/u-s-slaps-steel-aluminum-tariffs-on-canada-mexico-european-union-1527774283 
where $\mathrm{W}=$ social welfare, $u_{j}=$ utility (happiness, actually perfection) ${ }^{62}$ of person $\mathrm{j}, \mathrm{j}=1,2,3$, $\ldots \mathrm{N}, \mathrm{L}=$ labor, $\mathrm{K}=$ capital, $\mathrm{T}$ = land (territory), and $\mathrm{E}=$ entrepreneurship.

The social welfare function is analogous to the consumer theory of indifference curve and budget constraint tangency for an individual, except that the social welfare function is a mapping of individual preferences or judgments of everyone in the society as to collective choices, which apply to all, whatever individual preferences are for (variable) constraints on factors of production. ${ }^{63}$ Welfare is the provision of a minimal level of wellbeing and social support for the citizens of a country. In most developed countries, welfare is mainly provided by the government from tax revenue, and to a lesser extent by other social groups and organizations. Social security expands on this concept, especially in welfare states, ${ }^{64}$ by providing all citizens with various social services such as universal healthcare, unemployment insurance, free education, and others.

The total national income of the economy $(\mathrm{Y})$ is used for paying taxes $(\mathrm{T})$, for consumption $(\mathrm{C})$, and for saving $(S)$ :

$$
Y_{t}=T_{t}+C_{t}+S_{t}
$$

The national production ( $\mathrm{Y}$ ) can be used for consumption (C), for investment (I), for government spending $(\mathrm{G})$, for exports $(\mathrm{X})$, and a proportion from this aggregate demand (AD) is imported (M):

$$
Y_{t}=C_{t}+I_{t}+G_{t}+X_{t} \quad M_{t}
$$

The production of a nation must exceed its spending (domestic absorption) and this excess production must be exported. From eqs. (2) and (3), we derive eq. (4):

$$
Y_{t} \quad E_{t}=\left(\begin{array}{ll}
T_{t} & G_{t}
\end{array}\right)+\left(\begin{array}{ll}
S_{t} & I_{t}
\end{array}\right)=X_{t} \quad M_{t}=T A_{t}>0
$$

where, $\mathrm{Y}=$ income (GDP), $\mathrm{E}=\mathrm{C}+\mathrm{I}+\mathrm{G}=$ domestic expenditures (absorption), $\mathrm{C}=$ consumption, $\mathrm{T}=$ taxes (government revenue), $\mathrm{G}=$ government spending, $\mathrm{S}=$ saving, $\mathrm{I}=$ investment, $\mathrm{X}=$ exports, $\mathrm{M}=$ imports, and $\mathrm{TA}=$ trade account.

These exports and imports make up the trade account that depends on terms of trade and domestic and foreign income.

$$
\begin{aligned}
& X_{t}={ }_{0}+{ }_{1} T O T_{t}+{ }_{2} Y_{t}^{*}+{ }_{t} \\
& X_{t}={ }_{0}+{ }_{1} \frac{e_{t} P_{t}^{*}}{P_{t}}+{ }_{2} Y_{t}^{*}+{ }_{t}
\end{aligned}
$$

\footnotetext{
62 The objective of a human being (person) is to reach perfection ( $\tau \varepsilon \lambda \varepsilon$ เótns, $\tau$ ) and not a simple economic utility based on consumption. Thus, to reach perfection: $\tau=\mathrm{f}$ [knowledge, true wisdom, words, actions, way of living, values, virtues, true faith, democracy, freedom, relations with others, family, country, tradition, education, consumption, investment, etc.]. Subject to socially imposed constraints: s. c. = [environment, "enemy", society, media (fake news and misinformation), peer pressure, laws and regulations, political system, income, wealth, etc.].

63 See, Layard and Walters (1978).

64 The welfare state is a concept of government, in which the state plays a key role in the protection and promotion of the social and economic wellbeing of its citizens. It is based on the principles of equality of opportunity, equitable distribution of wealth, and public responsibility for those unable to avail themselves of the minimal provisions for a good life. The general term may cover a variety of forms of economic and social organization. The welfare state involves a transfer of funds from the state to the services provided (i.e. healthcare, education, etc.) as well as directly to individuals ("benefits"), and is funded through taxation. It is often referred to as a type of mixed Aristotelian economy. Such taxation must include a larger income tax for people with higher incomes (a progressive tax system). This helps reduce the income gap between the rich and poor.
} 


$$
\begin{aligned}
& M_{t}={ }_{0} \quad{ }_{1} \operatorname{TOT}_{t}+{ }_{2} Y_{t}+{ }_{t} \\
& M_{t}={ }_{0} \quad \frac{e_{t} P_{t}^{*}}{P_{t}}+{ }_{2} Y_{t}+{ }_{t} \\
& \text { and } \operatorname{TOT}_{t}=\frac{P_{M_{t}}}{P_{X_{t}}}=\frac{e_{t} P_{t}^{*}}{P_{t}}<1
\end{aligned}
$$

because of the low cost of production abroad. $\left(P_{t}^{*}<P_{t} \quad P_{M_{t}}<P_{X_{t}}\right)$.

where, $X_{t}=$ exports, $M_{t}=$ imports, $T O T_{t}=$ terms of trade, $P_{M_{t}}=$ price of imports, $P_{X_{t}}=$ price of exports, $e_{t}=$ spot exchange rate, $P_{t}=$ domestic price, $P_{t}^{*}=$ foreign price, $Y_{t}=$ domestic income, and $Y_{t}^{*}=$ foreign income.

There has also been concern that international trade could operate against the interests of some countries. The prices in China are very low due to low cost of production; turning the terms of trade (TOT) against the developed countries and producing an unintended transfer of wealth from the U.S. to China and other developing countries. Then, the country has to protect its own economy and citizens by imposing a tariff, which improves competitiveness.

$$
\begin{aligned}
& \operatorname{TOT}_{t}(1+t)=\frac{P_{M_{t}}}{P_{X_{t}}}(1+t) \quad 1 \\
& P_{M_{t}}(1+t) \quad P_{X_{t}}
\end{aligned}
$$

where, $\mathrm{t}=$ tariff.

The term "infant industry" is used to denote a new industry, which has prospects of gaining comparative advantage in the long-term, but which would be unable to survive in the face of competition from imported goods and the "deserted industry", due to inhumane globalization, which has to be protected for the benefits of the country and its welfare. This situation can occur when time is needed either to achieve potential economies of scale, or to acquire potential learning curve economies, or to reach potential market shares inside the country. Successful identification of such situations, followed by the imposition of a barrier against imports can, in principle, produce substantial benefits to the country that applies it - a policy known as "import substitution industrialization". Whether such policies succeed depends upon the governments' skills in picking winners, with reasonably expectations of successes. It has been claimed that South Korea's automobile industry owes its existence to initial protection against imports, but a study of infant industry protection in Turkey reveals the absence of any association between productivity gains and degree of protection, such as might be expected of a successful import substitution policy. The deserted industry is a new economic state imposed by globalists and accepted by corrupted dealers (followers).

Economists' liberal and theoretical findings about the benefits of trade have in some cases been rejected by government policy-makers, who have frequently sought to protect domestic industries against foreign competition by erecting barriers, such as tariff $(\mathrm{t})$ and import quotas, against imports. Of course, this was the reason that citizens voted for their leader, to satisfy the wellbeing of the country. Average tariff levels of around $15 \%$ in the late 19 th century rose to 
about 30\% in the 1930s, following the passage in the United States of the Smoot-Hawley Act. ${ }^{65}$ Mainly as the result of international agreements under the auspices of the General Agreement on Tariffs and Trade (GATT) and subsequently the World Trade Organization (WTO), ${ }^{66}$ average tariff levels were progressively reduced to about $7 \%$ during the second half of the 20th century, and some other trade restrictions were also removed. ${ }^{67}$ The trade restrictions that remain are nevertheless of major economic importance and necessary to protect the countries, which have lost their comparative advantage. U.S. has to protect manufacture and agriculture with trade policies. ${ }^{68}$ In the OECD countries government payments account for $30 \%$ of farmers' receipts and tariffs of over $100 \%$ are common.

Quotas prompt foreign suppliers to raise their prices toward the domestic level of the importing country. That relieves some of the competitive pressure on domestic suppliers, and both they and the foreign suppliers gain at the expense of a loss to consumers, but it is offset with higher employment and income for the domestic economy. When quotas were banned under the rules of the General Agreement on Tariffs and Trade (GATT), the United States, Britain and the European Union made use of equivalent arrangements known as voluntary restraint agreements (VRAs) or voluntary export restraints (VERs), which were negotiated with the governments of exporting countries (mainly Japan), until they too were banned. Tariffs have been considered to be less harmful than quotas, although their welfare effects differ only when there are significant downward trends in imports. When a country imposes import restrictions must increase domestic production to satisfy the demand of its citizens and maintains the social welfare in high levels. Governments also impose a wide range of non-tariff barriers that are similar in effect to quotas, some of which are subject to WTO agreements. A recent example has been the application of the precautionary principle to exclude innovatory products. ${ }^{69}$

Unfortunately, U.S. cannot compete with the Asian economies because of the low cost of production there and in other cases there is trade dumping, too..$^{70}$ Especially, it cannot compete with China, which has a unique social and economic system, complete different from the Western socio-economic culture. In China $50 \%$ of the business belong to the local government

\footnotetext{
65 The Tariff Act of 1930 (codified at 19 U.S.C. ch. 4), commonly known as the Smoot-Hawley Tariff or Hawley-Smoot Tariff, was an act implementing protectionist trade policies sponsored by Senator Reed Smoot and Representative Willis C. Hawley and was signed into law on June 17,1930. The act raised U.S. tariffs on over 20,000 imported goods.

66 General Agreement on Tariffs and Trade (GATT) was a legal agreement between many countries, whose overall purpose was to promote international trade by reducing or eliminating trade barriers such as tariffs or quotas. According to its preamble, its purpose was the "substantial reduction of tariffs and other trade barriers and the elimination of preferences, on a reciprocal and mutually advantageous basis". It was first discussed during the United Nations Conference on Trade and Employment and was the outcome of the failure of negotiating governments to create the International Trade Organization (ITO). GATT was signed by 23 nations in Geneva on October 30, 1947, and took effect on January 1, 1948. It remained in effect until the signature by 123 nations in Marrakesh on April 14, 1994, of the Uruguay Round Agreements, which established the World Trade Organization (WTO) on January 1, 1995. The WTO is a successor to GATT, and the original GATT text (GATT 1947) is still in effect under the WTO framework, subject to the modifications of GATT 1994.

67 This unfair policy against the developed nations by these suspicious international institutions is destructive for the citizens of the U.S. and Europe. These institutions are talking about the overall global benefits by removing of all trade restrictions, but the benefits are for China and not for the U.S.

${ }^{68}$ Canada has import tariffs on U.S. agricultural products. See, https://www.export.gov/article?id=Canada-Import-Tariffs

69 The precautionary principle (or precautionary approach) generally defines actions on issues considered to be uncertain, for instance applied in assessing risk management. The principle is used by policy makers to justify discretionary decisions in situations where there is the possibility of harm from making a certain decision (e.g. taking a particular course of action) when extensive scientific knowledge on the matter is lacking. The principle implies that there is a social responsibility to protect the public from exposure to harm, when scientific investigation has found a plausible risk. These protections can be relaxed only if further scientific findings emerge that provide sound evidence that no harm will result.

70 See, https://japantrade.wordpress.com/2013/04/27/dumping-in-international-trade/
} 
and the other $50 \%$ is owned by a private (mostly MNC) firm. ${ }^{71}$ The cost of production in China is very small and they afford to sell their products at a very low price. ${ }^{72}$ The labor cost in the U.S. is 30 times the Chinese wages. In 2018, U.S. tries to put some tariffs to protect its domestic industries (i.e., on Aluminum, steel, etc.) and China is retaliating with tariffs on U.S. agricultural products. ${ }^{73}$ China is also becoming a military power threatening the neighboring countries by building artificial islands in South China Sea. ${ }^{74}$

\section{A THEORETICAL MODEL OF DOLLAR'S VALUATION}

The correlation and the causality tests between the exchange rate and some macro-variables ${ }^{75}$ reveal that the exchange rate $[\mathrm{e}(\$ / €)]$ is affected by the following variables:

$$
e_{t}=f\left(C A_{t}, K A_{t}, Y_{t}, E_{t}, S_{t}, I_{t}, N D_{t}, C P I_{t}, D J A_{t}, i_{F F_{t}}, i_{S T_{t}}, i_{G B_{t}}, P_{\text {oil }}, P_{\text {Gold }_{t}}, W D_{t}, E D C D_{t}\right)
$$

where, $\mathrm{e}=$ exchange rate, $\mathrm{CA}=$ current account, $\mathrm{KA}=$ capital account, $\mathrm{Y}=$ income, $\mathrm{E}=$ expenditures $(E=C+I+G), \mathrm{S}=$ saving, $\mathrm{I}=$ investment, $\mathrm{ND}=$ national debt, $\mathrm{CPI}=$ consumer price index, DJIA = Dow Jones Industrial Average, $\mathrm{i}_{\mathrm{FF}}=$ federal funds rate, $\mathrm{i}_{\mathrm{s}-\mathrm{T}}=$ short-term interest rate, $\mathrm{i}_{\mathrm{GB}}=$ government bonds rate, $\mathrm{P}_{\mathrm{oil}}=$ oil price domestic, $\mathrm{P}_{\mathrm{Gold}}=$ price of gold, $\mathrm{WD}=$ Iraqi war dummy ( 0 before March 2003 and 1 since March 2003), and EDCD = European debt crisis dummy (0 before October 2009 and 1 since October 2009).

The trade account (TA) of the country can be presented with the following equation, which is a combination of eqs. $\left(5^{\prime}\right)$ and $\left(6^{\prime}\right)$,

$$
T A_{t}={ }_{0}+{ }_{1}\left(\frac{e_{t} P_{t}^{*}}{P_{t}}\right)+{ }_{2} Y_{t}+{ }_{3} Y_{t}^{*}+{ }_{t}
$$

We can write eq. (10) as a general function, in natural logarithms,

$$
t a_{t}=f\left(e_{t}, p_{t}^{*}, p_{t}, y_{t}, y_{t}^{*}\right)
$$

Then, we solve eq. $\left(10^{\prime}\right)$ for $e_{t}$,

$$
e_{t}=f\left(t a_{t}, p_{t}^{*}, p_{t}, y_{t}, y_{t}^{*}\right)
$$

The capital account can be written as:

$$
K A_{t}=C A_{t}={ }_{0}+{ }_{1}\left(i_{t} i_{t}^{*}\right)+{ }_{t}
$$

where, $\mathrm{KA}=$ capital account, $\mathrm{i}=$ domestic interest rate, and $\mathrm{i}^{*}=$ foreign interest rate .

We substitute $C A_{t}$ and $K A_{t}$ in eq. (9) with eqs. (10) and (11) and we generate a new equation in ln eq. $\left(9^{\prime}\right)$, which gives the $e_{t}$ determination and we test the following function in $\ln$ :

$$
\begin{aligned}
e_{t}= & f\left(c a_{t}, k a_{t}, y_{t}, \ln E_{t}, \ln E_{t}, \ln S_{t}, \ln I_{t}, n d_{t}, \text { djia }_{t}, i_{F F_{t}}, i_{S T_{t}}, i_{G B_{t}}, p_{\text {oil }_{t}}, p_{\text {Gold }_{t}}, W D, E D C D_{t},\right. \\
& \left.p_{t}^{*}, p_{t}, y_{t}, y_{t}^{*}\right)
\end{aligned}
$$

\footnotetext{
${ }^{71}$ See, Chong-En Baiy, Chang-Tai Hsiehz, and Zheng (Michael) Songx, "Crony Capitalism with Chinese Characteristics", This version: May 2014. EXTREMELY PRELIMINARY AND INCOMPLETE http://china.ucsd.edu/_files/pe-2014/10062014_Paper_Bai_Chong.pdf

${ }_{72}$ Cost of living in China is $38.18 \%$ lower than in United States (aggregate data for all cities, rent is not taken into account). Rent in China is $51.68 \%$ lower than in United Sates (average data for all cities). See, some prices in China: https://www.numbeo.com/cost-of-living/country_result.jsp?country=China

73 President Trump promised relief to U.S. farmers caught up in his administration's burgeoning trade dispute with China. See, The Wall Street Journal, April 10, 2018, pp. A1 and A2.

${ }^{74}$ China has installed military jamming equipment on two of its fortified outposts in the South China Sea. See, The Wall Street Journal, April 10, 2018, pp. A1 and A2. The U.S. with the U.K. and France bombed Syria with 105 tomahawk missiles to show their power to Russia, Iran, Syria, North Korea, and why not to China. (Fox News, April 13, 2018). These people cannot abandon the Cold War; it has been institutionalized to the West by the dark powers, the enemies of Truth.

75 See, Kallianiotis (2010, p. 50).
} 
Through substitution of eqs. (2), (3), (10), and (11), we receive:

$$
\ln e_{t}=\frac{0}{1} \ln P_{t}^{*}+\ln P_{t}+\frac{1}{1} \ln N D_{t}+\frac{1}{1} \ln K A_{t} \quad \frac{2}{1} \ln Y_{t} \quad \frac{3}{1} \ln Y_{t}^{*}+{ }_{t}
$$

where, $K A_{t}$ can be substituted with the $C A_{t}$ and with $\left(i_{t} \quad i_{t}^{*}\right)$, too.

Further, we can test the effects of the price of oil $\left(P_{\text {oil }}\right)$, national debt $\left(N D_{t}\right)$, current account ( $C A_{t}$ ), war dummy ( $W D$ ), and European debt crisis dummy ( $\left.E D C D\right)$.

$$
\ln e_{t}={ }_{0}+{ }_{1} \ln P_{\text {oil }}+{ }_{2} \ln N D_{t}+{ }_{3} \ln C A_{t}+{ }_{4} W D+{ }_{5} E D C D+{ }_{t}
$$

Thus, eqs. $\left(9^{\prime}\right),\left(10^{\prime \prime}\right),(12)$, and (13) can be used to determine the factors that affect the exchange rate (the value of the dollar). An increase of the direct exchange rate $\left(e_{t}\right)$ means a depreciation of the U.S. dollar.

\section{EMPIRICAL RESULTS}

It is important to test the above theory by applying data from the two economies, U.S.A. and Euro-zone. The data, taken from economagic.com, imfstatistics.org, Eurostat, and Bloomberg.com are monthly from 1999:01 to 2017:12. They comprise, spot exchange rate (e), consumer price indexes in U.S. and EMU (CPI and CPI*), federal funds rate ( $\mathrm{i}_{\mathrm{FF}}$ ), 3-month T-bill rate $\left(\mathrm{i}_{\mathrm{RF}}\right), \mathrm{ECB}$ overnight rate (ionD), nominal $\left(\mathrm{Y}\right.$ and $\left.\mathrm{Y}^{*}\right)$, private consumption $(\mathrm{C})$, private investment (I), exports (X), imports (M), current account (CA), capital account (KA), taxes (T), government expenditures (G), national debt (ND), personal saving rate (psr), USXRI = U.S. exchange rate index, DJIA = Dow Jones Industrial Average Index, USM2 and EUM2 = U.S. and EU money supply, $\mathrm{P}_{\text {oil }}=$ price of oil, $\mathrm{P}_{\text {Gold }}=$ price of gold, $\mathrm{WD}=$ Iraqi war dummy, and $\mathrm{EDCD}=$ European debt crisis dummy; thus, variables for the U.S. and the Euro-zone economies.

First, the correlation coefficients between all these variables are presented in Table 1 . We see a very high positive correlation between the exchange rate (dollar's devaluation) $[\mathrm{e}(\$ / €)]$ and the exports (X), imports (M), current account deficit (CA) or capital account surplus (KA), U.S. $(\mathrm{Y})$ and foreign $\left(\mathrm{Y}^{*}\right)$ income, U.S. and foreign prices (CPI and CPI*), consumption (C), U.S. exchange rate index (USXRI), price of oil ( $\mathrm{P}_{\text {oil }}$ ), price of gold ( $\left.\mathrm{P}_{\mathrm{Gold}}\right)$, and war dummy (WD). Also, a small positive correlation exists with the U.S. saving (S), investment (I), the U.S. national debt (ND), taxes (T), money supplies (USM2 and EUM2), Dow Jones industrial average (DJIA), and European debt crisis dummy (EDCD). Any increase in these variables depreciates the U.S. dollar. The current account (CA) has a negative correlation with the spot exchange rate (e). An improvement of the current account (CA), decreases the exchange rate (dollar is appreciated). A negative correlation (dollar's appreciation) appears with respect the domestic (i) and foreign $\left(i^{*}\right)$ interest rates. Any increase in these two interest rates, appreciates the dollar. (Lately, when the interest rate has declined so much in the U.S., the dollar has depreciated drastically). Now, the interest rate $\left(i_{F F}=2 \%\right)$ is going up and we expect some appreciation of the dollar.

Table 2 shows the Granger causality test between the variables in question. The imports (M), the foreign income $\left(\mathrm{Y}^{*}\right)$, the exchange rate index (USXRI), the capital account (KA), and the war dummy (WD) cause the depreciation of the U.S. dollar. The current account (CA) causes the appreciation of the dollar. The foreign income $\left(\mathrm{Y}^{*}\right)$ and the war dummy (WD) cause the depreciation of the dollar, measuring with the exchange rate index (USXRI), too. Further, an increase of spot exchange rate (e) or depreciation of the dollar cause an increase to exports (X), 
imports (M), foreign income $\left(\mathrm{Y}^{*}\right)$, national debt (ND), and inflation (CPI). An increase in the spot rate (depreciation of the dollar) cause a decline to the interest rates (i and $\mathrm{i}^{*}$ ). Also, the war dummy (WD) and the foreign income ( $\mathrm{Y}^{*}$ ) cause the dollar to depreciate (USXRI). The appreciation of the dollar through the increase of the USXRI causes a decline of exports (X), imports $(\mathrm{M})$, income $(\mathrm{Y})$, foreign income $\left(\mathrm{Y}^{*}\right)$, national debt $(\mathrm{ND})$, price level (CPI), price of gold ( $\left.\mathrm{P}_{\text {Gold }}\right)$, money supply (M2), and price of oil ( $\left.\mathrm{P}_{\text {oil }}\right)$.

Table 1

Correlation Coefficients between Exchange Rate and other Important Macro-variables

\begin{tabular}{|c|c|c|c|c|c|c|c|c|c|c|c|c|c|c|c|c|c|}
\hline & $\mathrm{e}$ & $X$ & $\mathrm{M}$ & $\mathrm{Y}$ & $\mathrm{Y}^{*}$ & $\mathrm{~S}$ & I & ND & CPI & $\mathrm{T}$ & $\mathrm{C}$ & CPI* & CA & $\mathrm{KA}$ & $\mathrm{i}$ & $\mathrm{i}^{*}$ & USXRI \\
\hline e & 1.000 & & & & & & & & & & & & & & & & \\
\hline X & 0.498 & 1.000 & & & & & & & & & & & & & & & \\
\hline $\mathrm{M}$ & 0.582 & 0.973 & 1.000 & & & & & & & & & & & & & & \\
\hline $\mathrm{Y}$ & 0.538 & 0.965 & 0.966 & 1.000 & & & & & & & & & & & & & \\
\hline $\mathrm{Y}^{*}$ & 0.530 & 0.884 & 0.837 & 0.864 & 1.000 & & & & & & & & & & & & \\
\hline $\mathrm{S}$ & 0.180 & 0.668 & 0.537 & 0.609 & 0.763 & 1.000 & & & & & & & & & & & \\
\hline I & 0.319 & 0.909 & 0.901 & 0.911 & 0.702 & 0.484 & 1.000 & & & & & & & & & & \\
\hline ND & 0.315 & 0.955 & 0.893 & 0.939 & 0.839 & 0.735 & 0.905 & 1.000 & & & & & & & & & \\
\hline CPI & 0.509 & 0.977 & 0.963 & 0.994 & 0.877 & 0.651 & 0.910 & 0.960 & 1.000 & & & & & & & & \\
\hline $\mathrm{T}$ & 0.315 & 0.926 & 0.914 & 0.933 & 0.736 & 0.514 & 0.980 & 0.931 & 0.933 & 1.000 & & & & & & & \\
\hline $\mathrm{C}$ & 0.557 & 0.964 & 0.969 & 0.992 & 0.861 & 0.612 & 0.885 & 0.930 & 0.990 & 0.910 & 1.000 & & & & & & \\
\hline CPI* & 0.750 & 0.704 & 0.735 & 0.712 & 0.747 & 0.501 & 0.440 & 0.579 & 0.713 & 0.475 & 0.772 & 1.000 & & & & & \\
\hline $\mathrm{CA}$ & -0.552 & -0.301 & -0.512 & -0.401 & -0.170 & 0.266 & -0.341 & -0.138 & -0.346 & -0.330 & -0.419 & -0.419 & 1.000 & & & & \\
\hline KA & 0.552 & 0.301 & 0.512 & 0.401 & 0.170 & -0.266 & 0.341 & 0.138 & 0.346 & 0.330 & 0.419 & 0.419 & -1.000 & 1.000 & & & \\
\hline i & -0.383 & -0.642 & -0.581 & -0.676 & -0.751 & -0.730 & -0.486 & -0.706 & -0.709 & -0.499 & -0.687 & -0.599 & 0.010 & -0.010 & 1.000 & & \\
\hline i* & -0.317 & -0.740 & -0.667 & -0.760 & -0.745 & -0.745 & -0.644 & -0.852 & -0.780 & -0.675 & -0.755 & -0.527 & 0.001 & -0.001 & 0.780 & 1.000 & \\
\hline \multirow{2}{*}{ USXRI } & $\mathrm{I}-0.948$ & -0.624 & -0.685 & -0.628 & -0.660 & -0.337 & -0.387 & -0.450 & -0.608 & -0.394 & -0.656 & -0.856 & 0.511 & -0.511 & 0.444 & 0.449 & 1.000 \\
\hline & & $\mathrm{X}$ & M & $Y$ & $\mathrm{Y}^{*}$ & $\mathrm{~S}$ & I & ND & CPI & $\mathrm{T}$ & $\mathrm{C}$ & CPI* & CA & KA & $\mathrm{i}$ & $i^{*}$ & USXRI \\
\hline DJIA & 0.069 & 0.793 & 0.754 & 0.752 & 0.508 & 0.414 & 0.907 & 0.837 & 0.765 & 0.911 & 0.728 & 0.218 & -0.166 & 0.166 & -0.337 & -0.576 & -0.147 \\
\hline USM2 & 0.305 & 0.939 & 0.893 & 0.949 & 0.799 & 0.936 & 0.937 & 0.988 & 0.964 & 0.955 & 0.936 & 0.541 & -0.198 & 0.198 & -0.696 & -0.820 & -0.409 \\
\hline EUM2 & 0.457 & 0.962 & 0.932 & 0.988 & 0.860 & 0.674 & 0.915 & 0.970 & 0.991 & 0.936 & 0.976 & 0.663 & -0.269 & 0.269 & -0.712 & -0.800 & -0.554 \\
\hline OPD & 0.826 & 0.678 & 0.738 & 0.710 & 0.650 & 0.314 & 0.450 & 0.472 & 0.635 & 0.455 & 0.669 & 0.836 & -0.528 & 0.528 & -0.405 & -0.330 & -0.883 \\
\hline GOLD & 0.540 & 0.930 & 0.888 & 0.890 & 0.881 & 0.756 & 0.732 & 0.892 & 0.911 & 0.761 & 0.910 & 0.812 & -0.207 & 0.207 & -0.716 & -0.771 & -0.705 \\
\hline FFR & -0.360 & -0.622 & -0.559 & -0.658 & -0.740 & -0.734 & -0.464 & -0.698 & -0.692 & -0.481 & -0.669 & -0.583 & -0.004 & 0.004 & 0.994 & 0.802 & 0.428 \\
\hline $10 \mathrm{YTB}$ & $3-0.390$ & -0.860 & -0.818 & -0.874 & -0.831 & -0.754 & -0.766 & -0.900 & -0.895 & -0.778 & -0.885 & -0.666 & 0.178 & -0.178 & 0.851 & 0.820 & 0.506 \\
\hline WD & 0.759 & 0.679 & 0.773 & 0.788 & 0.646 & 0.299 & 0.629 & 0.607 & 0.749 & 0.633 & 0.793 & 0.713 & -0.670 & 0.670 & -0.544 & -0.601 & -0.773 \\
\hline \multirow[t]{2}{*}{ EDCD } & 0.256 & 0.871 & 0.784 & 0.809 & 0.815 & 0.789 & 0.711 & 0.916 & 0.841 & 0.760 & 0.810 & 0.578 & 0.001 & -0.001 & -0.705 & -0.844 & -0.445 \\
\hline & DJIA & USM2 & EUM2 & OPD & GOLD & FFR & $10 \mathrm{YTB}$ & $3 \mathrm{WD}$ & EDCD & & & & & & & & \\
\hline DJIA & 1.000 & & & & & & & & & & & & & & & & \\
\hline USM2 & 0.861 & 1.000 & & & & & & & & & & & & & & & \\
\hline EUM2 & 0.780 & 0.977 & 1.000 & & & & & & & & & & & & & & \\
\hline OPD & 0.255 & 0.436 & 0.556 & 1.000 & & & & & & & & & & & & & \\
\hline GOLD & 0.597 & 0.845 & 0.895 & 0.710 & 1.000 & & & & & & & & & & & & \\
\hline FFR & -0.321 & -0.685 & -0.696 & -0.373 & -0.700 & 1.000 & & & & & & & & & & & \\
\hline 10YTB & $3-0.611$ & -0.893 & -0.895 & -0.478 & -0.875 & 0.837 & 1.000 & & & & & & & & & & \\
\hline WD & 0.402 & 0.635 & 0.716 & 0.629 & 0.643 & -0.536 & -0.654 & 1.000 & & & & & & & & & \\
\hline EDCD & 0.699 & 0.860 & 0.845 & 0.473 & 0.891 & -0.701 & -0.824 & 0.467 & 1.000 & & & & & & & & \\
\hline
\end{tabular}

Note: $\mathrm{e}=$ spot exchange rate, $\mathrm{X}=$ exports, $\mathrm{M}=$ imports, $\mathrm{Y}=\mathrm{U} . \mathrm{S}$. nominal income, $\mathrm{Y}^{*}=\mathrm{EMU}$ nominal income, $\mathrm{S}=$ personal saving rate, $\mathrm{I}=$ private investment, $\mathrm{ND}=$ national debt, $\mathrm{CPI}=$ consumer price indexes in $\mathrm{U} . \mathrm{S}$., $\mathrm{T}=$ tax revenue, $\mathrm{C}=$ private consumption, $\mathrm{CPI}^{*}=\mathrm{EMU}$ consumer price index, $\mathrm{CA}=$ current account, $\mathrm{KA}=$ capital account, $\mathrm{i}=3$-month $\mathrm{T}$-bill rate, $\mathrm{i}^{*}=\mathrm{ECB}$ overnight rate, USXRI = U.S. exchange rate index, DJIA = U.S. Dow Jones Industrial Average, USM2 = U.S. Money Supply (M2), EUM2 = EU Money Supply (M2), OPD = price of oil, GOLD = price of gold, FFR = U.S. federal funds rate, 10YTB = U.S. 10 year treasury-bonds rate, $\mathrm{WD}=$ Iraqi war dummy, and $\mathrm{EDCD}=$ European debt crisis dummy.

Source: economagic.com, imfstatistics.org, Eurostat, and Bloomberg.com. 
Table 2

Pairwise Granger Causality Tests between the Exchange Rate and other Macro-variables

\begin{tabular}{|c|c|c|c|c|c|c|c|c|c|c|c|c|c|c|c|c|c|}
\hline & $\mathrm{X}$ & $\mathrm{M}$ & $\mathrm{Y}$ & $\mathrm{Y}^{*}$ & $\mathrm{~S}$ & I & ND & CPI & $\mathrm{T}$ & $\mathrm{C}$ & USXR & I CA & KA & $\mathrm{i}$ & $i^{*}$ & $\mathrm{P}_{\text {oil }}$ & WD \\
\hline$X=>e$ & - & $2.805^{* *}$ & - & $2.681^{* *}$ & - & - & - & - & - & - & $4.210^{* * *}$ & $3.653^{* *}$ & $3.653^{* *}$ & & - & - & $3.126^{* *}$ \\
\hline \multirow[t]{2}{*}{$e=>X$} & $5.250^{* * *}$ & ${ }^{*} 3.061^{* *}$ & - & $4.203^{* * *}$ & - & - & $4.972^{* * *}$ & $4.785^{* * *}$ & - & - & - & - & - & $5.388^{* * *}$ & $3.587^{* *}$ & - & \\
\hline & $\mathrm{X}$ & $\mathrm{M}$ & $\mathrm{Y}$ & $\mathrm{Y}^{*}$ & $\mathrm{~S}$ & I & ND & CPI & PGold & WD & CPI* & $\mathrm{CA}$ & KA & $\mathrm{i}$ & $i^{*}$ & M2 & $P_{o i l}$ \\
\hline $\mathrm{X}=>$ USXR & - & - & - & $5.580^{* * *}$ & & - & - & - & - & $4.569^{* * *}$ & - & - & - & - & - & - & - \\
\hline USXRI $=>$ X & $7.246^{* * *}$ & $4.049^{* * *}$ & $2.690^{* *}$ & $4.779^{* * *}$ & * - & - & $3.695^{* *}$ & $2.325^{*}$ & $2.138^{*}$ & - & - & - & - & - & $2.625^{*}$ & $2.440^{*}$ & $6.777^{* * *}$ \\
\hline
\end{tabular}

Note: See, Table 1, e = EUS = dollar per euro exchange rate $(\$ / \epsilon), \mathrm{P}_{\mathrm{oil}}=$ price of oil, WD = war dummy (0 before March 2003 and 1 after March $2003, * * *=$ significant at the $1 \%$ level, $* *=$ significant at the $5 \%$ level, and $*=$ significant at the $10 \%$ level.

Source: See, Table 1.

Then, Table 3 shows the estimates of exchange rate by using eqs. (9) and (13). Domestic income (Y), consumption (C), price of oil ( $\mathrm{P}_{\mathrm{oil}}$ ), and the war dummy (WD) have a significant positive effect on the exchange rate (dollar is depreciated). The current account (ln $C A_{t}$ ), the investment $\left(\ln \mathrm{I}_{\mathrm{t}}\right)$, the national debt $\left(\ln N \mathrm{~N}_{\mathrm{t}}\right)$, and the European debt crisis dummy (EDCD) have a significant negative effect on the exchange rate (dollar is appreciated). Further, an autoregressive (AR) and a moving average (MA) processes are used to reduce the serial correlation of the error term $\left({ }_{t}\right)$. This correction has increased the D-W statistic from 0.079 and 0.346 to $2.027,1.783$, and 2.011 . 
Table 3

Factors Affecting the U.S. Dollar (Exchange Rate Determination) [Eqs. (9) and (13)]

\begin{tabular}{|c|c|c|c|c|c|c|}
\hline Variables & $\ln e_{t}$ & $\ln e_{t}$ & $\ln e_{t}$ & $\ln e_{t}$ & $\ln e_{t}$ & $\ln e_{t}$ \\
\hline $\mathrm{C}$ & $\begin{array}{l}-10.371^{* * *} \\
(1.158)\end{array}$ & $\begin{array}{l}-0.691^{* *} \\
(0.339)\end{array}$ & $\begin{array}{l}-8.479^{* * *} \\
(1.009)\end{array}$ & $\begin{array}{l}1.567 \\
(0.962)\end{array}$ & $\begin{array}{l}-3.632^{* * *} \\
(1.264)\end{array}$ & $\begin{array}{c}0.151 \\
(0.398)\end{array}$ \\
\hline \multirow[t]{2}{*}{$\ln K A_{t}$} & -0.031 & -0.004 & 0.028 & $-0.191^{* * *}$ & 0.032 & -0.012 \\
\hline & $(0.053)$ & $(0.013)$ & $(0.031)$ & $(0.037)$ & $(0.031)$ & $(0.016)$ \\
\hline \multirow[t]{2}{*}{$\ln Y_{t}$} & $1.804^{* * *}$ & 0.091 & $0.962^{* * *}$ & $0.543^{*}$ & $0.775^{* *}$ & 0.085 \\
\hline & $(0.428)$ & $(0.111)$ & $(0.327)$ & $(0.285)$ & $(0.334)$ & $(0.118)$ \\
\hline \multirow[t]{2}{*}{$\ln C_{t}$} & 0.476 & $0.205^{* *}$ & 0.236 & $-0.478^{* *}$ & -0.014 & 0.076 \\
\hline & $(0.412)$ & $(0.103)$ & $(0.241)$ & $(0.250)$ & $(0.308)$ & $(0.105)$ \\
\hline \multirow{2}{*}{$p s r_{t}$} & 0.003 & 0.001 & 0.002 & -0.002 & 0.003 & 0.001 \\
\hline & $(0.006)$ & $(0.001)$ & $(0.002)$ & $(0.004)$ & $(0.002)$ & $(0.001)$ \\
\hline \multirow[t]{2}{*}{$\ln I_{t}$} & $-0.386^{* * *}$ & -0.014 & $-0.170^{* *}$ & $-0.142^{* *}$ & -0.119 & -0.041 \\
\hline & $(0.097)$ & $(0.025)$ & $(0.070)$ & $(0.066)$ & $(0.077)$ & $(0.028)$ \\
\hline \multirow[t]{2}{*}{$\ln N D_{t}$} & $-0.403^{* * *}$ & -0.030 & $-0.373^{* * *}$ & 0.064 & -0.145 & 0.063 \\
\hline & $(0.115)$ & $(0.029)$ & $(0.093)$ & $(0.122)$ & $(0.100)$ & $(0.050)$ \\
\hline \multirow[t]{2}{*}{$\ln P_{t}$} & -0.759 & -0.307 & 0.363 & -0.286 & -0.354 & -0.367 \\
\hline & $(0.816)$ & $(0.203)$ & $(0.550)$ & $(0.552)$ & $(0.610)$ & $(0.225)$ \\
\hline \multirow[t]{2}{*}{$\ln P_{o i l_{t}}$} & - & - & - & $0.225^{* * *}$ & $0.120^{* * *}$ & $0.031^{* * *}$ \\
\hline & & & & $(0.015)$ & $(0.017)$ & $(0.009)$ \\
\hline \multirow[t]{2}{*}{$W D$} & - & - & - & $0.257^{* * *}$ & $0.045^{* *}$ & $0.024^{*}$ \\
\hline & & & & $(0.024)$ & $(0.018)$ & $(0.012)$ \\
\hline \multirow[t]{2}{*}{$E D C D$} & - & - & - & $-0.091^{* * *}$ & -0.009 & $-0.033^{* *}$ \\
\hline & & & & $(0.033)$ & $(0.020)$ & $(0.013)$ \\
\hline \multirow[t]{2}{*}{$\ln e_{t 1}$} & - & $1.124^{* * *}$ & - & - & - & $1.069^{* * *}$ \\
\hline & & $(0.067)$ & & & & $(0.067)$ \\
\hline \multirow[t]{2}{*}{$\ln e_{t 1}$} & - & $-0.183^{* * *}$ & - & - & - & $-0.212^{* * *}$ \\
\hline & & $(0.065)$ & & & & $(0.064)$ \\
\hline \multirow[t]{2}{*}{$M A(1)$} & - & - & $1.406^{* * *}$ & - & $1.336^{* * *}$ & - \\
\hline & & & $(0.058)$ & & $(0.067)$ & \\
\hline \multirow[t]{2}{*}{$M A(2)$} & - & - & $1.440^{* * *}$ & - & $1.291^{* * *}$ & - \\
\hline & & & $(0.089)$ & & $(0.094)$ & \\
\hline \multirow[t]{2}{*}{$M A(3)$} & - & - & $1.048^{* * *}$ & - & $0.920^{* * *}$ & - \\
\hline & & & $(0.093)$ & & $(0.092)$ & \\
\hline \multirow[t]{2}{*}{$M A(4)$} & - & - & $0.518^{* * *}$ & - & $0.428^{* * *}$ & - \\
\hline & & & $(0.065)$ & & $(0.067)$ & \\
\hline$R^{2}$ & 0.582 & 0.975 & 0.959 & 0.856 & 0.966 & 0.976 \\
\hline$S S R$ & 2.107 & 0.127 & 0.207 & 0.724 & 0.171 & 0.118 \\
\hline$F$ & 43.721 & 929.375 & 418.060 & 129.219 & 403.354 & 737.528 \\
\hline$D \quad W$ & 0.079 & 2.027 & 1.783 & 0.346 & 1.848 & 2.011 \\
\hline$N$ & 228 & 226 & 228 & 228 & 228 & 226 \\
\hline
\end{tabular}

Note: See, Tables 1 and 2. $\ln P_{\text {oil }}=$ natural logarithm of price of oil, $W D=$ war dummy $(0$ before 2003:03 and 1 afterward), and $E D C D=$ the European debt crisis dummy (0 before 2009:10 and 1 after).

Source: See, Table 1.

Now, Table 4 represents eq. (12). The foreign price level (ln $\mathrm{P}^{*}$ ) and the U.S. national income 
(ln Y) have a significant positive effect on the exchange rate (dollar is depreciated). The domestic price level (ln P), the U.S. national debt (ln ND), and the interest differential (i-i*) have a significant negative effect on the exchange rate (dollar is appreciated). Also, an AR(1) and a MA(4) processes are used to reduce the serial correlation of the error term $\left({ }_{t}\right)$ and the D-W statistic is improved.

Table 4

Factors Affecting the Devaluation of the U.S. Dollar [Eq. (12)]

\begin{tabular}{|c|c|c|c|c|c|c|}
\hline Variables & $\ln e_{t}$ & $\ln e_{t}$ & $\ln e_{t}$ & $\ln e_{t}$ & $\ln e_{t}$ & $\ln e_{t}$ \\
\hline $\mathrm{C}$ & $\begin{array}{l}-10.068^{* * *} \\
(1.048)\end{array}$ & $\begin{array}{l}-8.874^{* * *} \\
(1.016)\end{array}$ & $\begin{array}{l}-4.779^{* *} \\
(2.310)\end{array}$ & $\begin{array}{l}-0.953^{* * *} \\
(0.357)\end{array}$ & $\begin{array}{l}-9.986^{* * *} \\
(0.729)\end{array}$ & $\begin{array}{l}-4.781^{* *} \\
(2.099)\end{array}$ \\
\hline $\ln P_{t}^{*}$ & $\begin{array}{l}1.098^{* * *} \\
(0.129)\end{array}$ & $\begin{array}{l}0.464^{* * *} \\
(0.076)\end{array}$ & $\begin{array}{l}0.017 \\
(0.230)\end{array}$ & $\begin{array}{l}0.135^{* * *} \\
(0.042)\end{array}$ & $\begin{array}{l}1.090^{* * *} \\
(0.127)\end{array}$ & $\begin{array}{l}0.001 \\
(0.253)\end{array}$ \\
\hline $\ln P_{t}$ & $\begin{array}{l}-1.713^{* * *} \\
(0.639)\end{array}$ & $\begin{array}{l}0.301 \\
(0.521)\end{array}$ & $\begin{array}{c}0.706 \\
(0.517)\end{array}$ & $\begin{array}{l}-0.235 \\
(0.186)\end{array}$ & $\begin{array}{l}-1.232^{*} \\
(0.733)\end{array}$ & $\begin{array}{c}0.644 \\
(0.501)\end{array}$ \\
\hline $\ln N D_{t}$ & $\begin{array}{l}-0.263^{* * *} \\
(0.095)\end{array}$ & $\begin{array}{l}-0.392^{* * *} \\
(0.102)\end{array}$ & $\begin{array}{l}-0.284^{* *} \\
(0.130)\end{array}$ & $\begin{array}{l}-0.013 \\
(0.028)\end{array}$ & $\begin{array}{l}-0.296^{* * *} \\
(0.091)\end{array}$ & $\begin{array}{l}-0.287^{* * *} \\
(0.108)\end{array}$ \\
\hline $\ln K A_{t}$ & $\begin{array}{l}-0.025 \\
(0.041)\end{array}$ & $\begin{array}{l}0.003 \\
(0.030)\end{array}$ & $\begin{array}{l}0.002 \\
(0.033)\end{array}$ & $\begin{array}{l}-0.007 \quad i_{t} \quad i_{t}^{*} \\
(0.012)\end{array}$ & $\begin{array}{l}0.008 \\
(0.006)\end{array}$ & $\begin{array}{l}-0.014^{*} \\
(0.008)\end{array}$ \\
\hline $\ln Y_{t}$ & $\begin{array}{l}1.707^{* * *} \\
(0.326)\end{array}$ & $\begin{array}{l}0.851^{* * *} \\
(0.275)\end{array}$ & $\begin{array}{c}0.395 \\
(0.285)\end{array}$ & $\begin{array}{l}0.209^{* *} \\
(0.098)\end{array}$ & $\begin{array}{l}1.415^{* * *} \\
(0.324)\end{array}$ & $\begin{array}{l}0.448^{*} \\
(0.256)\end{array}$ \\
\hline $\ln Y_{t}^{*}$ & $\begin{array}{l}0.088 \\
(0.057)\end{array}$ & $\begin{array}{l}0.108 \\
(0.067)\end{array}$ & $\begin{array}{l}-0.002 \\
(0.055)\end{array}$ & $\begin{array}{l}-0.029^{*} \\
(0.017)\end{array}$ & $\begin{array}{l}0.129^{* *} \\
(0.058)\end{array}$ & $\begin{array}{l}-0.010 \\
(0.055)\end{array}$ \\
\hline $\ln e_{t 1}$ & - & - & - & $\begin{array}{l}1.118^{* * *} \\
(0.067)\end{array}$ & - & - \\
\hline $\ln e_{t 1}$ & - & - & - & $\begin{array}{l}-0.186^{* * *} \\
(0.066)\end{array}$ & - & - \\
\hline$A R(1)$ & - & - & $\begin{array}{l}0.970^{* * *} \\
(0.018)\end{array}$ & - & - & $\begin{array}{l}0.971^{* * *} \\
(0.018)\end{array}$ \\
\hline$M A(1)$ & - & $\begin{array}{l}1.352^{* * *} \\
(0.061)\end{array}$ & $\begin{array}{l}0.168^{* *} \\
(0.065)\end{array}$ & - & - & $\begin{array}{l}0.178^{* *} \\
(0.075)\end{array}$ \\
\hline$M A(2)$ & - & $\begin{array}{l}1.368^{* * *} \\
(0.088)\end{array}$ & - & - & - & - \\
\hline$M A(3)$ & - & $\begin{array}{l}0.987^{* * *} \\
(0.095)\end{array}$ & - & - & - & - \\
\hline$M A(4)$ & - & $\begin{array}{c}0.489^{* * *} \\
(0.066)\end{array}$ & - & - & - & - \\
\hline$R^{2}$ & 0.686 & 0.961 & 0.974 & 0.975 & 0.688 & 0.974 \\
\hline$S S R$ & 1.580 & 0.195 & 0.133 & 0.126 & 1.569 & 0.131 \\
\hline$F$ & 80.583 & 486.769 & 889.847 & $1,055.019$ & 81.406 & 907.461 \\
\hline$D \quad W$ & 0.127 & 1.813 & 1.958 & 2.033 & 0.126 & 1.956 \\
\hline$N$ & 228 & 228 & 228 & 226 & 228 & 228 \\
\hline
\end{tabular}

Note: See, Tables 1 and 2.

Source: See, Table 1. 
Finally, Table 5 reveals the empirical results of eqs. (10) and (11), where the devaluation of the dollar $\left(e_{t}+p_{t}^{*} p_{t}\right)$ improves the current account (CA). An increase in the U.S. income (Y) reduces the current account (CA). An increase in the European income ( $\mathrm{Y}^{*}$ ) improves the current account (CA). Also, it shows the price (-0.692) and income elasticities (domestic, -1.838 and foreign, 0.918) of the current account and the positive effects of interest rates (i-i*) on the capital account. AR (1) processes are used to improve the D-W statistic, too.

Table 5

Current and Capital Account [Eqs. (10) and (11)]

\begin{tabular}{|c|c|c|c|c|c|c|}
\hline Variables & $\ln C A_{t}$ & $\ln C A_{t}$ & & $\ln K A_{t}$ & & $\ln K A_{t}$ \\
\hline$C$ & $\begin{array}{l}3.695^{* * *} \\
(0.744)\end{array}$ & $\begin{array}{c}0.072 \\
(0.218)\end{array}$ & $C$ & $\begin{array}{c}6.070^{* * *} \\
(0.309)\end{array}$ & & $\begin{array}{l}5.906^{* * *} \\
(0.408)\end{array}$ \\
\hline$e_{t}+p_{t}^{*} \quad p_{t}$ & $\begin{array}{l}-0.692^{* * *} \\
(0.076)\end{array}$ & $\begin{array}{l}-0.055^{* *} \\
(0.025)\end{array}$ & $i_{t} i_{t}^{*}$ & $\begin{array}{l}-0.022 \\
(0.015)\end{array}$ & $i_{t}$ & $\begin{array}{l}0.010 \\
(0.021)\end{array}$ \\
\hline $\ln Y_{t}$ & $\begin{array}{l}-1.838^{* * *} \\
(0.140)\end{array}$ & $\begin{array}{l}-0.146^{* * *} \\
(0.051)\end{array}$ & & - & $i_{t}^{*}$ & $\begin{array}{c}0.050^{* * *} \\
(0.017)\end{array}$ \\
\hline $\ln Y_{t}^{*}$ & $\begin{array}{l}0.918^{* * *} \\
(0.098)\end{array}$ & $\begin{array}{l}0.104^{* * *} \\
(0.032)\end{array}$ & $\mathrm{AR}(1)$ & $\begin{array}{l}0.992^{* * *} \\
(0.011)\end{array}$ & $\operatorname{AR}(1)$ & $\begin{array}{l}0.995^{* * *} \\
(0.009)\end{array}$ \\
\hline $\ln C A_{t-1}$ & - & $\begin{array}{c}0.925^{* * *} \\
(0.018)\end{array}$ & & & & \\
\hline$R^{2}$ & 0.555 & 0.964 & & 0.963 & & 0.964 \\
\hline$S S R$ & 7.499 & 0.571 & & 0.631 & & 0.613 \\
\hline$F$ & 93.220 & 1505.330 & & 1921.946 & & 1477.900 \\
\hline$D \quad W$ & 0.119 & 2.060 & & 1.981 & & 2.099 \\
\hline$N$ & 228 & 227 & & 228 & & 228 \\
\hline
\end{tabular}

Note: See, Tables 1 and 2.

Source: See, Table 1.

\section{SOME HISTORICO-ECONOMICO-SOCIO-POLITICAL CONSIDERATIONS}

From 1792, when the Mint Act was passed, the dollar was defined as 371.25 grains (24.056 g) of silver. Some historians assume gold was standardized at a fixed rate in parity with silver. Alexander Hamilton suggested to Congress a fixed 15:1 ratio of silver to gold. ${ }^{76}$ The gold coins that were minted were not given any denomination whatsoever and traded for a market value relative to the Congressional standard of the silver dollar. In 1834 it was a shift in the gold standard to 23.2 grains ( $1.50 \mathrm{~g}$ ), followed by a slight adjustment to 23.22 grains (1.505 g) in 1837 (16:1 ratio). In 1862, paper money was issued without the backing of precious metals, due to the Civil War. Silver and gold coins continued to be issued and in 1878 the link between paper money and coins was reinstated. The use of paper money not backed by precious metals had also occurred under the Articles of Confederation from 1777 to 1788 . With no solid backing and being easily counterfeited, the continentals quickly lost their value, giving rise to the phrase "not worth a continental". ${ }^{77}$

The Gold Standard Act of 1900 abandoned the bimetallic standard and defined the dollar as 23.22 grains $(1.505 \mathrm{~g}$ ) of gold, equivalent to setting the price of 1 troy ounce of gold at $\$ 20.67$. Silver coins continued to be issued for circulation until 1964, when all silver was removed from

76 In Ancient Greece, this ratio was 10:1. See, Kallianiotis (2016). https://arpgweb.com/pdf-files/ijefr2(2)16-32.pdf 77 See, Kallianiotis (2013 and 2017b). 
dimes and quarters, and the half dollar was reduced to $40 \%$ silver. Silver half dollars were last issued for circulation in 1970. Gold coins were confiscated by Executive Order 6102 issued in 1933 by Franklin Roosevelt. The gold standard was changed to 13.71 grains $(0.888 \mathrm{~g})$, equivalent to setting the price of 1 troy ounce of gold at $\$ 35$. This standard persisted until 1968. Between 1968 and 1975, a variety of pegs to gold were put in place. According to the Bureau of Engraving and Printing, the largest note it ever printed was the $\$ 100,000$ Gold Certificate, Series 1934. These notes were printed from December 18, 1934 through January 9, 1935, and were issued by the U.S. Treasurer to Federal Reserve Banks only against an equal amount of gold bullion held by the Treasury. These notes were used only for transactions between Federal Reserve Banks; they were not circulated among the general public.

\section{The Current Global Economic Strife}

Today, the international financial and monetary system (and the exchange rate) is very different from what it was 30 years ago. It is, lately, in the process of evolving into a new stage through globalization, which its first effect became visible globally in August 2007 with the global financial crisis and continues to alter our socio-economic structure. ${ }^{78}$ With the new President, Donald Trump, there is some hope to be some delays to this inhumane trend by the dark powers. ${ }^{79}$ The one constant innovation of this free-market system was and still is to maximize the market value of the financial assets, which is subjective, selfish, and costly for our society. Financial institutions play a critical, but very delicate role, since they are themselves value maximizing enterprises, creators of money from "thin air", and innovators of any kind of new instruments (even "toxic" ones). Our economy is ultimately dependent on the viability of its financial institutions and markets, all of which are owned by an "economic elite" (the group of 13) and institutional investors (hedge funds, insurance, pension funds, etc.). The interest expense (payment) has become a very large proportion of the monthly income for households. The same holds for governments, where their interest payments make up a huge amount of their government spending $(G)$. Thus, the focus is on financial markets and businesses, which are legal entities, and not on households and people, who are the base and the apex of our society. These market prices (values) have caused serious instability, anxiety, risk, loss of wealth, and enormous psychological problems. Lately, these greedy and directed markets had difficulties satisfying their objectives, which was investments and transferring of capital between savers (suppliers of funds) and investors (demanders of funds).

This modern capitalism involves the acquisition of expensive assets (real and financial) by borrowing (mortgages, car loans, etc. and buying securities with only $50 \%$ cash, margin requirements and the rest of their value with call money loans), which is a very risky process. The entire economy is based on financial leverage and by paying a higher risk premium everyone can borrow money. This system that was imposed in West, from capitalism became debtism. The interest rate determines who gets credit. Over an extended period of boom, high growth, and enormous liquidity, economies tend to move from a financial structure dominated by hedge financing to a structure with increasing speculative financing. The shift towards

\footnotetext{
78 The globalist managing director of IMF, Christine Lagarde, said the economies will become cashless by making enigmatic statements, even using the term "magic" and talking about numerology. She was communicating a message on behalf of the "elite" regarding the future of the global financial system. Two weeks later, at a Bloomberg interview at the World Economic Forum, she said that it is important to "reset" the global economy. (sic). Lagarde communicated her belief and by implication,

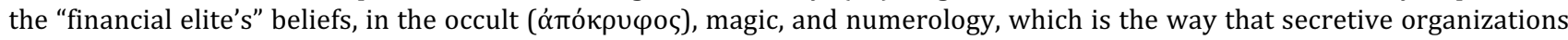
make decisions and plans for the world. For Christine Lagarde's speech at the National Press Club in Washington, D.C. in early 2014, see, McGuire and Anderson (2018, pp. 214-219).

79 Rudy Giuliani, the lawyer of President Trump said that "a group of 13 with Mueller try to frame President Trump". TV News Fox, June 6, 2018. See also, Kallianiotis (2017a).
} 
speculative positions occurs intentionally and more or less inevitably because of innovations and overoptimistic expectations ("irrational exuberance"). ${ }^{80}$ The shift from speculative toward ponzi finance occurs because of lack of regulations, corruption, unethical business practices, and everything that led the world, where we are today, trying for ten years to recover from a global financial crisis ${ }^{81}$ and a new one seems in the horizon.

After World War II, England lost its superiority and Germany was ruined with its fallacious decision to impose its will on Europeans militarily. ${ }^{82}$ Since the Korean War (June, 251950 July 27, 1953) until 2007, the U.S.A. was concurrently the biggest economic, military, and monetary power in the world, with its currency, the dollar, to be the number one reserve currency of the world, due to the Bretton Woods Agreement (1944), with which all the basic commodities are priced and with this currency all transactions in the international commodities exchanges take place. The global dominium (dominance) of dollar made the new greater economy of the world, China, to peg its currency, the yuan, to the dollar and following a policy, which is a monetary war between the two nations and is increasing daily. China has become the most severe competitor of the U.S. ${ }^{83}$ Thus, the U.S. depreciated the dollar to improve its trade, but the pegged yuan reduced U.S. competitiveness and made China very competitive because of the low cost of production and the undervalued yuan. U.S. has to protect its domestic industries and create jobs for the American citizens. This is the main objective of public policies, the maximization of the welfare of the citizens.

The U.S. was impelling the depreciation of the dollar towards the other non-pegged with the dollar currencies. With this decline of the value of the dollar, the U.S. increases its competitiveness and decreases the competitiveness of the Euro-zone and of the other countries. The Euro-zone countries blame the U.S. for this dollar's depreciation. With more than $80 \%$ depreciation of the dollar, the U.S. has become more competitive during the decade of 2000s, where the European nations, due to the common currency have lost completely their competitiveness. But, China, by pegging the yuan with the dollar, enjoys the same benefits as the U.S. plus some extras, due to the enormous low cost of production. ${ }^{84}$ Then, these two countries are technically making discounts to their own products and overvaluing the ones of the other nations (unfair competitions).

The rest of the nations can sell their currencies and buy dollars and yuans to increase their values, but this is impossible (and costly, transaction cost), due to the size of these two large economies. Then, the only means to improve their trade is through tariffs and import taxes, and other quantitative and qualitative restrictions. ${ }^{85}$ The euro caused serious problems to the

${ }^{80}$ Even though that we have a bear market and a financial crisis that is followed by a recession approximately every ten years. See, Kallianiotis (2015).

81 See, Demitri B. Papadimitriou and L. Randall Wray, "Minsky's Analysis of Financial Capitalism", Working Paper No. 275, Jerome Levy Economics Institute, July 1999. See also, Eiteman, Stonehill, and Moffett (2010, pp. 106-134).

${ }^{82}$ Now, it imposes its will financially and economically without any war or resistance from the other Euro-zone nations. See, Kallianiotis (2018).

83 In 2011, the economic growth and the growth in stocks was: U.S. (1.8\% and $-0.9 \%)$ and China (9.0\% and $-22.2 \%)$. (The Wall Street Journal, December 5, 2011, p. C5). In 2017, the U.S. growth was (2.3\% and DJIA: $18.69 \%)$ and the Chinese was (6.9\% and Shanghai50: 5.25\%). See,

https://www.statista.com/statistics/188165/annual-gdp-growth-of-the-united-states-since-1990/

https://tradingeconomics.com/china/stock-market

84 In China, 1.34 billion people are working like ants and keep the wages to the lowest level compared with the other nations. The labor cost in China is about 15 yuan/hour (\$2.34/hour) and in U.S. the average hourly wage is $\$ 22.59 /$ hour, which is 9.65 times higher than the Chinese labor cost.

https://en.wikipedia.org/wiki/Minimum_wage_in_China . Also, https://tradingeconomics.com/united-states/wages 85 Trade barriers are government-induced restrictions on international trade. The barriers can take many forms, including the following: Tariffs, Non-tariff barriers to trade, Import licenses, Export licenses, Import quotas, Subsidies, Voluntary Export Restraints, Local content requirements, Embargo, Currency devaluation. Most trade barriers work on the same principle: the 
countries, which were forced to accept it and abandon their domestic national currencies; they lost their public policy, their independence, and their sovereignty. These countries with high debts and deficits became less and less competitive. Before, they were surviving by devaluating their currencies. ${ }^{86}$ Now, with the euro, the countries of the Euro-area lost their contingency to control their monetary and consequently their trade policies and have to do an "internal devaluation". ${ }^{87}$ These new monetary conditions brought the countries-members (except Germany ${ }^{88}$ to a very disadvantageous position. Greece, Portugal, Spain, Ireland, and Italy were destroyed with the overvaluation of the euro ${ }^{89}$ The Euro became the most expensive currency globally. Europeans cannot compete with the adoption of the euro; they can acquire their former public policies only if they would go back to their previous national currencies (at an initial exchange rate of 1 unit of their domestic currency per euro).

The paradox was the appreciation of the euro with respect to the U.S. dollar, at the time that the European economies were in deep recession. Euro had appreciated with respect to the U.S. dollar ${ }^{90}$ by $88.24 \%$ and the poor Europeans have to reduce their cost of production (internal devaluation) by 88\%, which has enormous social (impetuous poverty) and political (parliamentary dictatorship) cost. The adoption of the euro by the peripheral countries of the EU was a tremendous socio-economic mistake and the responsible politicians must be voted down for the prevalence of social justice. Bonitsis (2011) examined the stylized path of the competitiveness of the PIIGS nations and France's and Germany's by using the Harmonized Competitiveness Indicator (HCI). He found that Germany and France were at a competitive disadvantage and Portugal, Italy, Ireland, Greece, and Spain at a competitive advantage until 2000 and then, with the introduction of the euro, Germany became the dominant competitive country, followed by France. The PIIGS lost their competitiveness and now have to follow all these fiscal austerity measures imposed by the Troika. ${ }^{91}$

Further, Amstad and Martin (2011, p. 6, Chart 4) show that the central banks (Fed, ECB, Bank of England, and Swiss National Bank) assets were very close until 2008 (before the financial crisis) and then, there was a tremendous increase of the assets of the three central banks, but not of the ECB to provide the liquidity (reserves) and help their economies facing the recession. The Fed's increase of domestic credit (purchase of government securities and mortgage-back securities) was an astonishing ineffective monetary phenomenon. The ECB's increase of reserves supplying to the financial institutions was very small. This might have caused the continuation of the overvaluation of the euro (depreciation of the dollar) at the time that the debt crisis was keeping the Euro-zone in a deep recession. Why was this happening?

imposition of some sort of cost on trade that raises the price of the traded products. If two or more nations repeatedly use trade barriers against each other, then a trade war results. But, the ultimate objective of a nation must be the maximization of the social welfare of its citizens.

86 Thus, $T O T=\frac{P_{M}}{P_{X}}=\frac{e P^{*}}{P}>1 \quad P_{M}>P_{X} \quad T A=X \quad M>0$

87 Which is, $T O T=\frac{\bar{e} P^{*}}{P}>1 \quad \frac{P_{M}}{P_{X}} \quad P_{M}>P_{X} \quad T A=X \quad M>0$

${ }^{88}$ The DM was appreciated much more compared to the euro with respect to the U.S. dollar. Then, Germany is better off with the euro instead of its own currency, the DM.

${ }^{89}$ See, Kallianiotis (2018).

90 The exchange rate between dollar and euro was, in October 2000, e $=0.8500 \$ / €$ and reached in April 2008, e = 1.6001 $\$ / €$; an appreciation $88.24 \%$. On February 24, 2012, where the Euro-zone was under dissolution, it was $1.3463 \$ / €(58.39 \%$ appreciation). Then, the markets might know something for the U.S. economy that the rating firms, the politicians, the central bankers, and the economists do not know. Actually, we live in a delusion of a deceptive secular world.

91 See, Kallianiotis (2018). 
Who is dictating this anti-European policy? Who is dictating this anti-world policy of the Fed?92 The common currency and the common monetary policy in the Euro-zone have caused serious problems in the member-nations because they have different inflation rates and their economic growth and unemployment rates vary significantly, as well as their different competitiveness in trade and foreign investments. Nachio (2011) says that the target rate of the ECB does not fill all the Euro-zone members. The Taylor rule suggests lower target rates for the peripheral countries that have been caught in the sovereign debt crisis and higher federal funds rate for the U.S. by the Fed. The current monetary rule is in line with the Taylor rule recommendation in the core group (mostly in Germany). ${ }^{93}$ This is another disadvantage of the common monetary policy for distinctive and different nations. The problem of the U.S. economy was and is the high unemployment, ${ }^{94}$ which cannot be improved with monetary

\footnotetext{
92 President Woodrow Wilson said about the Fed: "I am a most unhappy man. I have unwittingly ruined my country. A great industrial nation is controlled by its system of credit. Our system of credit is concentrated. The growth of the nation, therefore, and all our activities are in the hands of a few men. We have come to be one of the worst ruled, one of the most completely controlled and dominated Governments in the civilized world -- no longer a Government by free opinion, no longer a Government by conviction and the vote of the majority, but a Government by the opinion and duress of a small group of dominant men." See,

https://www.salon.com/2007/12/21/woodrow_wilson federal_reserve/. While most would say the Federal Reserve was designed to stabilize the economy and prevent bank failures, more investigation shows that the Fed is a private banking cartel designed to work against the best interests of the American people. Woodrow Wilson was the president that signed the Federal Reserve legislation. See, https://politicalvelcraft.org/2012/09/16/did-woodrow-wilson-really-regret-handingamerica-to-the-rothschild-banksters/. See also, http://www.themoneymasters.com/the-money-masters/famous-quotationson-banking/

${ }_{93}$ According to Taylor's original version of the rule, the nominal interest rate should respond to divergences of actual inflation rates from target inflation rates and of actual Gross Domestic Product (GDP) from potential GDP:
}

$$
i_{t}={ }_{t}+r_{t}^{*}+\left(\begin{array}{cc} 
& * \\
t & t
\end{array}\right)+{ }_{y}\left(\begin{array}{ll}
y_{t} & \bar{y}_{t}
\end{array}\right)
$$

In this equation, $i_{t}$ is the target short-term nominal interest rate (e.g. the federal funds rate in the US or the ECB key interest rate, OND), ${ }_{t}$ is the rate of inflation as measured by the GDP deflator, ${ }_{t}^{*}$ is the desired rate of inflation, $r_{t}^{*}$ is the assumed equilibrium real interest rate, $y_{t}$ is the logarithm of real GDP or the unemployment rate $\left(u_{t}\right)$, and $\bar{y}_{t}$ is the logarithm of potential output, as determined by a linear trend or the natural level of unemployment $\left(u_{t}^{N}\right)$. In this equation, both $a_{\pi}$ and $a_{y}$ should be positive (as a rough rule of thumb, Taylor's 1993 paper proposed setting $a_{\pi}=a_{y}=0.5$ ). That is, the rule "recommends" a relatively high interest rate (a "tight" monetary policy) when inflation is above its target or when output is above its full-employment level, in order to reduce inflationary pressure. It recommends a relatively low interest rate ("easy" monetary policy) in the opposite situation, to stimulate output. Sometimes monetary policy goals may conflict, as in the case of stagflation, when inflation is above its target while output is below full employment. In such a situation, a Taylor rule specifies the relative weights given to reducing inflation versus increasing output. A simple version of the Taylor rule is:

$i_{O N D_{t}}^{E C B}=1+1.5$ t $1\left(u_{t} u_{t}^{N}\right)$

Thus, the target rates (November 2011) must be:

(1) Euro-zone: $0.2 \%=1+1.5(3 \%)-1(10.3 \%-5 \%)$, but it was $1 \%$ (high)

(2) Germany: $1.7 \%=1+1.5(2.4 \%)-1(6.9 \%-4 \%)$, but it was $1 \%$ (low)

(3) Greece: $-7.75 \%=1+1.5(3.1 \%)-1(18.4 \%-5 \%)$, but it was $1 \%$ (very high)

(4) Spain: $-11.15 \%=1+1.5(2.9 \%)-1(21.5 \%-5 \%)$, but it was $1 \%$ (very high)

(5) U.S.: $1.65 \%=1+1.5(3.5 \%)-1(8.6 \%-4 \%)$, but it was $0.25 \%$ (very low).

The ECB key interest rate was $1.25 \%$ the last two years and on December 8, 2011 was cut to 1\%, which benefits only Germany. The U.S. federal funds rate is $0.25 \%$ from December 2008 to December 2016 and did not help the domestic economy; it created only a new bubble in the financial markets. See, https://tradingeconomics.com/united-states/interest-rate. On June 13, 2018, the Fed raised the target federal funds rate to $2 \%$. See, https://www.wsj.com/articles/fed-raises-rates-and-signals-fasterpace-in-coming-years-1528912910.

94 The U.S. official unemployment is low (3.8\% with May 2018) because they changed the way measuring unemployment. The true unemployment is very high (21.5\% with April 2018). 
policy (zero interest rate), but with some fiscal policy ("large program of public works spending") $)^{95}$ and by bringing back manufacturing.

\section{Advantages of the U.S. Dollar as the World's Reserve Currency}

The U.S. has been able to get away with massive debts and unsustainable deficits for one simple reason. The U.S. dollar is still the world's reserve currency, as it has been effectively since World War II with the Bretton Woods Agreement (1944) and literally since the early 1970s. All governments and banks in the world accept and hold U.S. dollars as the comfortable majority of their reserves; thus, the U.S. is able to simply print more money whenever it cannot afford to pay for things that it needs.96 Besides this, the country can borrow money in its own currency at incredibly low interest rates that have approached close to zero. 97 This benefits the American citizens, since the national government is able to provide numerous social services that most other countries simply cannot afford. With the U.S. dollar as the reserve currency of the planet, oil and all commodities are all priced in dollars. This causes oil and the byproduct of gasoline to be incredibly cheap to Americans.98 The United States has become the wealthiest country in the world as a result of the dollar as reserve currency. Imports can all be paid for in dollars. This is only true in the United States. Other countries have to first change

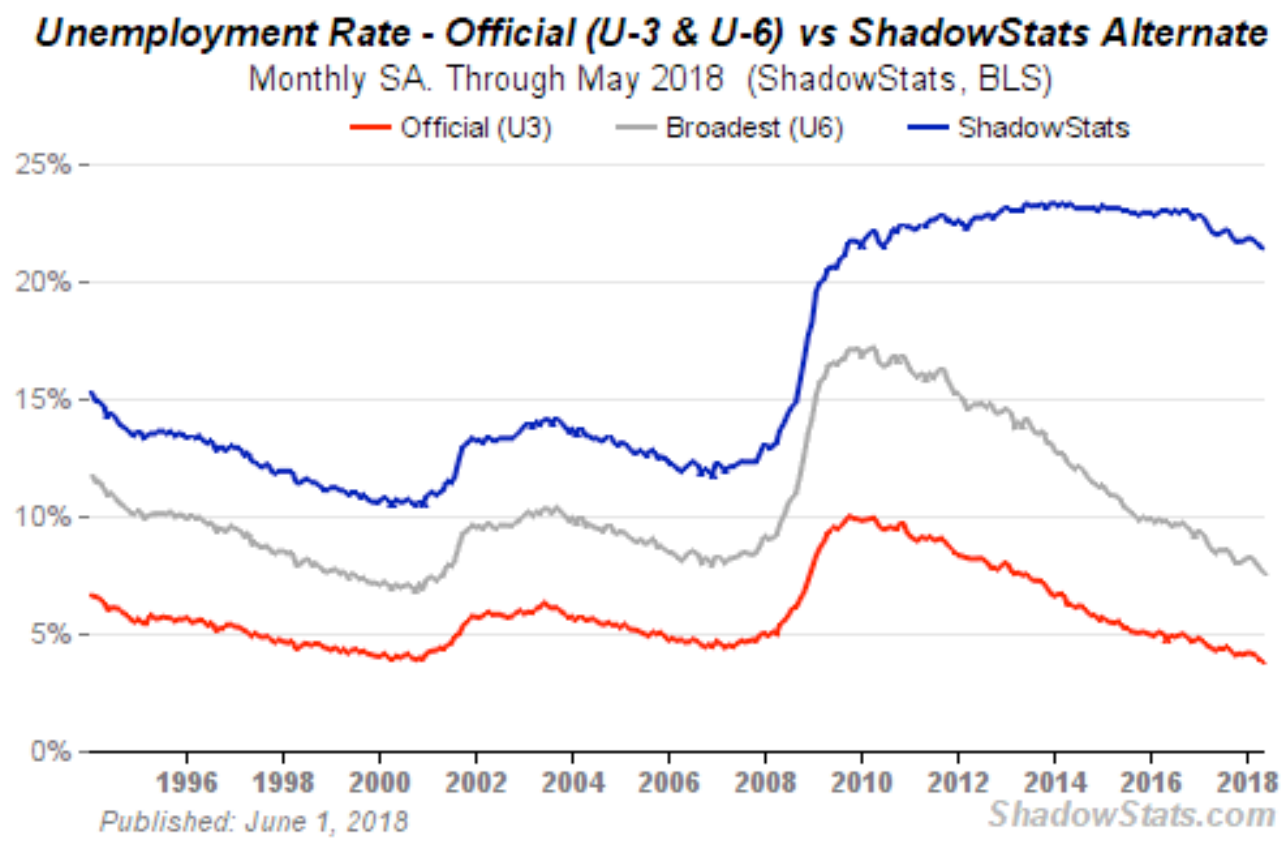

Source: http://www.shadowstats.com/alternate_data/unemployment-charts

Figure 2: U.S. Unemployment Rate

95 See, Krugman (2012).

96 The Monetary Base (MB) was $\$ 875$ billion in 2008 and reached $\$ 2,725$ billion in 2011. On February 6,2013 , it was $\$ 2,829$ billion; it peaked in September 3, 2014 (\$4,084 billion) and lately, June 6, 2018 was \$3,714 billion. See, http://research.stlouisfed.org/fred2/series/BASE

97 Treasury Bills rates were: $i_{3 M}=0.085 \%$ and $i_{6 M}=0.125 \%$ (February 24, 2012). In December 2011, the rate on 3-month T-Bills was $0.000 \%$. In June 14, 2018, they were $1.91 \%$ and $2.075 \%$ respectively, which are below the official inflation rate (2.5\%) (Economagic.com). The nominal deposit rate is still close to zero $\left(i_{D}=0.05 \%\right)$ that gives a negative real return of ( $r_{D}=2.45 \%$ ), which is completely unfair, unlawful, and a disincentive for the poor risk-averse depositors to save.

${ }^{98}$ Just compare how much other members of the richest nations whose currencies are not the reserve currency pay for their gasoline. While the U.S. average price of gas came in at $\$ 2.72$ per gallon, in Germany it was $\$ 6.82$ per gallon, in Great Britain it was $\$ 6.60$ a gallon, in Italy it was $\$ 6.40$ every gallon, in France it was $\$ 6.04$ a gallon, and in Japan it was $\$ 5.40$ for every gallon (data are from January 2011). In February 2013, the price of gas had reached in the U.S. the $\$ 4.25$ per gallon (a 56.25\% increase in two year). See, https://www.thebalance.com/why-are-gas-prices-so-high-3305653 
their currency into dollars to settle their balance of payments on imports and exports. With oil ${ }^{99}$ and other commodities cheaply priced in U.S. dollars, you see an enormous range of inexpensive goods available. Food items and other items that use oil and gas as input are extremely cheap. This makes restaurants and similar outings affordable in America. The level of wealth and excess seen in the U.S. is simply unprecedented, and most of this results from the benefits of the dollar as universal reserve currency.

Until the early 1970s, the U.S. was the world's largest creditor. This meant that the country loaned out more money to other countries than any other nation on earth. By the 1980s the country had begun to reverse this trend, becoming a debtor nation. It only took another decade to the 1990s to see the U.S. evolve into the world's largest debtor. The transformation has been dramatic, as the amount of debt that the country has taken on in the wake of the financial crisis and economic collapse is over twenty one (\$21.153) trillion dollars (121.87\% of the GDP). Total public and private debt is $\$ 156.96$ trillion (903.11\% of the GDP). ${ }^{100}$ The only reason that this has been possible is because other countries continuously loan America money at impossibly low interest rates. This is not the only way that the country "abuses" the status of owning the reserve currency. The United States also has printed money electronically since 2007 in increasingly larger amounts. The shocking truth is that America has more than quadrupled the amount of dollars $(M B=C+R)^{101}$ and $\left(M^{s}=m_{M} \cdot M B\right)^{102}$ in existence in the world in the last ten years. So far, other countries, in the grips of the devastating financial crisis, have grudgingly accepted this practice, although they have complained loudly over it. There is a high probability that the powerful countries will no longer tolerate this unfair advantage, especially in the future; China has already made public its opposition for the status of the dollar.

Of course, a number of things could happen to cause the country to lose its status of reserve currency. The oil producing cartel (OPEC) might finally make good on its threat to stop pricing oil in dollars, as it happened with Iran. ${ }^{103}$ Enough countries might decide to stop treating the dollar as reserve currency that it finally ceases to be the one. Another thing that could trigger this devastating event is that the U.S. might not be able to service the interest on its enormous debt, as some Euro-zone nations were facing, lately. This is a possibility that we see getting closer by the day, as the country is rapidly closing in on that time. We have transformed the American system from capitalism to debtism. There will be dramatic consequences in the U.S. that we can hardly imagine if the dollar finally ceases to be the reserve currency of the world. Should the dollar be dropped as reserve currency, then the value of the dollar will plummet. (Graph 3). The immediate painful effects will be that commodities' prices skyrocket. These would no longer be priced in U.S. dollars, and we would see the falling value of the dollar buy

\footnotetext{
${ }^{99}$ The price of oil is also used as a mean to punish producers or consumers. Its prices are determined in the futures market and are very suspicious. From $\$ 12 /$ barrel (1999:02) it went to $\$ 144$ (2008:07), then fell to $\$ 30$ (2016:02), and lately went up to $\$ 66.89$ /barrel (2018:06).

100 See, http://www.usdebtclock.org/ . Also, http://grandfather-economic-report.com/debt-summary-table.htm . In addition see, http://www.usdebtclock.org/world-debt-clock.html

101 Where, $\mathrm{MB}=$ monetary base, $\mathrm{C}=$ currency in circulation outside Federal Reserve Banks and the U.S. Treasury, and R = reserves (deposits) of depository financial institutions at Federal Reserve Banks. The MB from $\$ 864.113$ billion (June 2008) became $\$ 3,714.066$ billion (June 2018). See, https://fred.stlouisfed.org/series/BASE/

102 Where, $M^{s}=$ money supply, $m_{M}=$ money multiplier, and $M B=$ monetary base. The money supply from $\$ 4,744.7$ billion (May 2000) reached $\$ 14,065.7$ billion (May 2018). See, https://tradingeconomics.com/united-states/money-supply-m2 . Also, https://fred.stlouisfed.org/series/M2

103 The same happened with Saddam Hussein and Muammar Gaddafi. See, https://www.counterpunch.org/2013/03/22/theusa-attacked-iraq-because-saddam-had-wd/ . Also, https://thefreethoughtproject.com/declassified-emails-reveal-natos-truemotive-topple-gaddafi-stop-creation-gold-backed-african-currency/ and https://www.thenewamerican.com/economy/markets/item/4630-gadhafi-s-gold-money-plan-would-have-devastated-dollar . Further, http://anonhq.com/gaddafis-threat-to-the-us-petro-dollar-and-why-he-had-to-die/
} 
fewer and fewer commodities. Gasoline at five to ten dollars a gallon, as it is in Euro-zone, is not only possible, but highly likely. Along with higher gas prices would come higher prices for anything that is shipped or uses oil and gasoline as inputs. This means, practically, everything that Americans buy, from food stuffs and airline tickets, to cars and washing machines, would all cost dramatically more. As prices skyrocket, the lifestyle in the U.S. would sustain a punishing drop overnight.

Unfortunately, this is not the only consequence that we would see of a dollar that is no longer the reserve currency of the world. Interest rates would rise dramatically. They could easily reach $10 \%-15 \%$ or even higher. This would wreck housing prices far worse than they are today. It would also cause the stock market to crash and burn by maybe even half in a number of weeks. As the cost of supplies and materials goes up with the falling currency, businesses would be forced to cut back on employees in the light of their similarly falling sales. Unemployment could reach $20 \%-30 \%$ or more as a result of this, as it is in EU, today. As if this is not bad enough, inflation would be sky high along with the rising prices and disappearing jobs. ${ }^{104}$ Except, if the "economic elite" imposes a global common currency that is their ultimate objective. Our socio-political consideration must be to prevent and not to correct future crises and this can be done only with moderation, prudence, regulations, and a government that puts "America first" instead of the "allies first". ${ }^{105}$ The country, the institutions, the organizations, the agencies, the markets, and the society have many serious problems that are accumulated for many years and it is very difficult for the new administration to "drain this swamp".

\section{CONCLUSION}

The objective of this article is to determine the factors that have caused the volatility and depreciation of the international currency reserve, the U.S. dollar, the last fifteen (15) years, and its effects (positive and negative) on trade, wealth, and social welfare. The factors that have been determined, here, are the U.S. and European income, the U.S. excessive consumption (waste), the EMU prices, the low interest rates, the high prices, the foreign income, the low investment, the high price of oil, the U.S. national debt and deficits, the Middle East turmoil, which has increased the demand for euro, and speculation about the two economies (U.S. and Euro-zone). ${ }^{106}$ The exchange rate dynamics is based on shocks on the economy and on current

104 See, Thomas Herold, “What If The U.S. Dollar Loses Reserve Currency Status?”

http://www.wealthbuildingcourse.com/dollar-loses-reserve-currency-status.html

105 The inspector general released a report on FBI that shows the abuse of power and corruption in FBI working with a political bias against President Trump and protecting Hillary Clinton. Fox News, June 14, 2018. Also, "Report Blasts FBI Agents, Comey Over Clinton Probe", The Wall Street Journal, June 15, 2018, pp. A1 and A4.

106 Economy of Euro-zone (2011)

(1) GDP $=\$ 12,460$ billion

(2) Growth of GDP $=-0.3 \%$

(3) Inflation rate $=2.7 \%$

(4) Unemployment rate $=10 \%$

(5) Gross External Debt $=(\mathrm{NA})$

(6) Public Debt $=86 \%$ of the GDP

(7) Budget Deficit $=4.1 \%$ of the GDP

(8) GDP as a $\%$ of the U.S.A. $=92.83 \%$

(1) GDP $=\$ 13,423$ billion

(2) Growth of GDP $=1.7 \%$

(3) Inflation rate $=2.98 \%$

(4) Unemployment Rate $=8.5 \%$

(5) Gross External Debt $=\$ 8,400$ billion

(6) National Debt $=\$ 15,251$ billion; $113.62 \%$ of the GDP

(7) Budget Deficit $=\$ 1,300$ billion; $9.68 \%$ of the GDP 
account, due to oil prices, debts, and risk, between the U.S. dollar and the euro. Lately, the U.S. dollar has high volatility and has been losing value with respect to the euro and other major currencies of the world and certainty with gold (Graphs 1,2, and 3). We want to see if this depreciation depends on economic shocks and economic fundamentals; if it is just speculation from individuals and countries, which hold large amounts of foreign assets denominated in different currencies or due to the current global financial crisis, recessions, instability, and the risk that the U.S. might freeze the foreign funds invested in its assets.

The conclusion from this analysis can be that international investors, due to this cultivated global uncertainty (forced globalization through terrorism, economic crises, and displacing people), are investing in countries with higher return or lower risk, and safety, depending on their utility function and the modern systemic risk. This increase in demand for these assets increases the demand for currency in that country and its currency is appreciated; the oil prices, the high risk and the enormous debts are affecting the currency, too. Before 2001, people were invested in the U.S. and Japan, so the U.S. dollar and the Japanese yen were appreciated. After 2001, they invested in the Euro-zone and the U.K. and the dollar and yen lost their value. Of course, due to high risk of wars (in Iraq, Afghanistan, Syria, Ukraine, etc.) and the creeping ones (in North Korea ${ }^{107}$ and Iran), political conflicts, a unique financial crisis, low returns and recognition of Jerusalem as the capital of Israel; many speculators have invested in euros and other currencies, instead in dollars denominated assets. In the last months of 2012, we saw a change in this trend because of the Euro-zone debt problems, but did not last for long. The current account is affected by risk and high debts, too. Historically, the American governments have frozen the foreign assets inside the U.S., when a conflict arises. Investors know what is going on globally and act accordingly, so speculators take advantage of this knowledge. The international financial system will never become again as it was before 2007 because the terrorized people have lost their confidence for our social structure (weak democracies). ${ }^{108}$

The world is confronted by an intensifying technical ("creating") economic crisis of enormous magnitude that public policies cannot fix it with the current controlled system of central banking and the huge debts. Consequently, a new global financial and economic crisis is expected to erupt and become a global depression, which will lead the world to chaos. Globalist elite could stage an engineered global collapse and then, they would blame the Trump administration. The solution is the world leaders to come together and with a global cooperation to solve the problems of their citizens, their countries, and the world's at the end. The hope of people is an approach between the two most important world leaders, President

(8) GDP as a \% of Euro-zone $=107.73 \%$

(9) Total Debt (Public and Private) $=\$ 115.7$ trillion $+\$ 40.8$ trillion $=\$ 156.5$ trillion; $1,165.91 \%$ of the GDP

Then, U.S.A. is not doing better than the Euro-zone.

Why so much noise for the Euro-zone? There is no economic explanation. But, the dark powers want to control the Euro-zone member-nations and they terrorize their weak leaders with this constructed debt crisis.

107 Kim Jong Un of North Korea arrived in Singapore for summit with the U.S. President Donald Trump. See, http://www.foxnews.com/politics/2018/06/10/kim-jong-un-arrives-in-singapore-for-summit-with-trump.html. "See What Trump and Kim Signed in Singapore", https://www.wsj.com/articles/see-what-trump-and-kim-signed-in-singapore1528791608. Also, https://www.wsj.com/articles/trump-heralds-very-comprehensive-agreement-with-kim-jong-un1528783602?mod=article_inline . Furthermore, "Denuclearization: President Trump and Kim Jong Un End Historic Summit With Signing Ceremony". https://townhall.com/tipsheet/katiepavlich/2018/06/12/president-trump-and-kim-jong-un-endhistoric-summit-with-signing-ceremony-establishing-future-denuclearization-

n2489792?utm_source=thdailypm\&utm_medium=email\&utm_campaign=nl_pm\&newsletterad $=$. This Summit was historic and hopefully beneficial for the entire world. ABC News and Fox News, June 12, 2018.

108 Liberalism, capitalism, communism, globalism, atheism, etc. are all diseases of secularism, which have destroy our social and traditional value system. For example, the deaths from suicides exceed the deaths from car accidents. TV News $A B C$, June 7 , 2018. 
Donald Trump and President Vladimir Putin. Of course the dark powers are working very hard with all their means to prevent any cooperation between U.S. and Russia. ${ }^{109}$

The U.S. trade has not improved, even though that the dollar has depreciated because the price elasticity of demand for imports is inelastic $\left(\left.\right|_{M} \mid<1\right)$ and the income elasticity $\left({ }_{M}>1\right)$ is very elastic. U.S. had a very high income, high liquidity, low production (due to loss of manufacturing, outsourcing), and enormous borrowing, which increase the demand for foreign products (importables). The wealth of the U.S. citizens has declined by more than $50 \%$ because the dollar has depreciated up to $88 \%$ with respect the euro. Lastly, the social welfare had increased in 2000s, due to the increase of the stock market (wealth effect) which was artificial (bubble), reduction of official unemployment, and growth of income in the U.S.; but, in 2007, the financial crisis has caused serious problems to the real sector of the economy (recession, unemployment, loss of wealth in the financial market, and 40 million foreclosures). This is a tremendous social loss (reduction of social welfare) for the U.S. citizens and in late 2012, the "fiscal cliff" argument was monopolizing the discussions in politics and mass media. After the 2016 elections, the economy has started to recover, but the politics and the opposition from the party that lost the election (the Democratic Party) has caused enormous social, economic, and political cost for the country. Lately, the Inspector General destroyed DOJ and FBI credibility and people will start seeing what is going on with our (the "deep state") institutions. (sic) ${ }^{110}$

The response of the two policy rates $\left(i_{F F}\right.$ and $\left.i_{O N D}^{*}\right)$ on the exchange rate is a negative one for three months and then, it stays constant, which means [ $i \quad\left(M^{s}\right) e \quad(\$$ and euro $\left.)\right]$ a lot of volatility for 3 months (overshoots) ${ }^{111}$ and then, it stabilized at a lower level. Testing the effectiveness of monetary policy on the exchange rate,

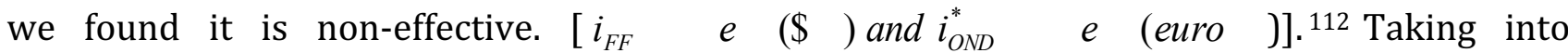
consideration the effect of the freezing funds risk premium (FFRP) on the exchange rate, we found that: $\left[F F R P\right.$ e (\$ and euro )], ${ }^{113}$ which is reasonable for our state of the

\footnotetext{
109 They try for two years to "prove" that there was a collusion between President Trump and Russia during the 2016 U.S. elections, which is impossible because it did not happened. See, https://sputniknews.com/russia/201710161058288903-trump-denies-russia-collusion-investigation/ . Also, https://www.rushlimbaugh.com/daily/2017/05/23/theres-no-evidence-of-trump-collusion-with-russia-so-the-focus-movesto-process-crimes/. Their objective is to "stop him" (Donald Trump) to win the elections. Fox News, June 12, 2018.

110 See, "A Review of Various Actions by the Federal Bureau of Investigation and Department of Justice in Advance of the 2016 Election". http://www.judicialwatch.org/wp-content/uploads/2018/06/DOJ-IG-Report-06-14-18.pdf

111 See, Dornbusch (1976) and Kallianiotis and Bianchi (2009).

112 The regression is:

$e_{t}=0.218^{* * *} \quad 0.024^{* * *} i_{F F_{t}} \quad 0.001 i_{\text {ond }}^{*}+1.503^{* * *}{ }_{t}{ }_{1}+0.947^{* * *} t_{2}$

$\begin{array}{llll}(0.051) \quad(0.009) \quad(0.016) & (0.025) \quad(0.023)\end{array}$

$R^{2}=0.882, \quad S S R=0.424, F=226.467$

113 These results are as following:$$
e_{t}=0.357+0.005^{* *} i_{O N D_{t}}^{*}+0.007^{* * *} F F R P_{t}+0.001^{* * *} f d_{\$_{t}}+0.990^{* * *} e_{t 1}+1.342^{* * *} t_{1}+0.356^{* * *} t_{2}
$$
$(0.506) \quad(0.002)$
(0.002)
$(0.001)$
(0.018)
(0.090)
(0.089)

$R^{2}=0.995, \quad S S R=0.019, \quad F=3,647.425$

Note: $e_{t}=$ ln of spot exchange rate, $i_{O N D_{t}}^{*}=$ ECB overnight deposit rate, $F F R P_{t}=$ freezing funds risk premium, $f d_{\$_{t}}=$ forward discount of the U.S. dollar, and $t_{t}=$ the error term.
} 
economy, due to the Middle-East and other crises and the historic memory with Japan in the past. After this analysis, we can say that the dollar could appreciate with respect to the euro, except if we have any other domestic (like, increase in trade deficit and public debt, increase in prices, fall in investment, and decrease in capital account, decrease of the federal funds rate or ECB rate, due to fear of recession) or external shocks on the two economies (oil prices, new wars, etc.). Still the forecasting of the exchange rate remains as a problem. The depreciation of the dollar and the protection of the domestic industries are beneficial for the economy. But, lately, any predictions for the future of our economic system have become almost impossible because the globalists are not afraid any more to pursue their destructive objective.

Finally, the problem, today, is that it has been abandoned the knowledge of optimism of the Ancient Greek moral philosophers and the wisdom of the hope of the revealed truth. Even though that it has been accumulated huge knowledge with the spectacular explosion of science, technology, and finance, the world has lost its hope, its true optimistic knowledge, the knowledge of truth, the Absolute Knowledge and the last global crisis proved our limited knowledge and we became illogically pessimists, which affects negatively our future. We hope the true education (and not the politically correct ignorance) to increase our true knowledge and improve the true (real) world. The current forced secularism has destroyed our traditional value system. There is some hope for changes in the U.S., due to the new administration and President Trump in power, ${ }^{114}$ who cares for the country first and then, for the rest of the world.

\section{References}

Amstad, Marlene and Antoine Martin (2011), "Monetary Policy Implementation: Common Goals but Different Practices", Current Issues in Economics and Finance, Federal Reserve Bank of New York, Volume 17, Number 7, pp. 1-9.

Baiy, Chong-En, Chang-Tai Hsiehz, and Zheng (Michael) Songx, "Crony Capitalism with Chinese Characteristics", This version: May 2014. EXTREMELY PRELIMINARY AND INCOMPLETE http://china.ucsd.edu/_files/pe2014/10062014_Paper_Bai_Chong.pdf

Bonitsis, Theologos Homer (2011), "Eurozone Competitiveness: An Analysis of the PIIGS", in 2011 Conference Proceedings Northeast Business \& Economics Association, Rajneesh Sharma (editor), Thirty-Eighth Annual Meeting, November 3-5, 2011, Sheraton Society Hill Hotel, Philadelphia, PA, U.S.A.

Bullard, James (2018), "Allan Meltzer and the Search for a Nominal Anchor”, Review, Federal Reserve Bank of St. Louis, Vol. 100, No. 2, pp. 117-126.

Dornbusch, Rudiger (1976), “Expectations and Exchange Rate Dynamics”, Journal of Political Economy, 84, pp. 1161-1176.

Eiteman, David K., Arthur I. Stonehill, and Michael H. Moffett (2010), Multinational Business Finance,12th Edition, Prentice Hall, Boston, U.S.A.

Francois, Joseph and Hugo Rojas-Romagosa (2011), “Household Inequality, Social Welfare, and Trade”, Journal of Development Economics, Vol. 96, Issue 2, November, pp. 422-431.

Gavin, William T. (2018), "Monetary Policy Regimes and the Real Interest Rate”, Review, Federal Reserve Bank of St. Louis, Vol. 100, No. 2, pp. 151-169.

Heller, H. Robert (1973), International Trade: Theory and Empirical Evidence, Englewood Cliffs, N.J.: Prentice-Hall, Inc.

Kallianiotis, John N. (2018), European Union and its Debt Crises: The Deception of the Greeks, Hauppauge, N.Y.: Nova Science Publishers.

114 On June 8-9, 2018, it was the G7 Summit in Canada and President Trump said that "Russia must be in the meeting; why we keep Russia out?" (TV News Fox, June 8, 2018). Russia is a European Christian Orthodox country and has similar value system with the U.S. and the West. 


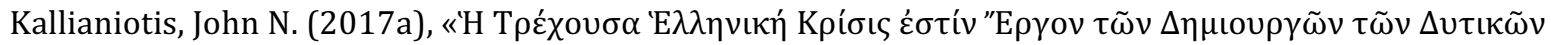

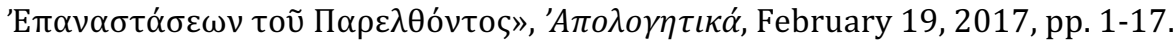

http://apologitikaa.blogspot.com.cy/2017/02/i.html

Kallianiotis, John N. (2017b), "Central Banks, Monetary Policy, and their Efficiency”, (Chapter 1) in Monetary Policy: Perspectives, Strategies and Challenges, Harriet Ward (editor), New York: Nova Science Publishers.

Kallianiotis, I. N. (2016), “The Economic History of Alexander the Great Expedition”, International Journal of Economics and Financial Research, Vol. 2, No. 2, pp. 16-32. https://arpgweb.com/pdf-files/ijefr2(2)16-32.pdf

Kallianiotis, John N. (2015), “The Latest 'Planned' Financial Crisis, Which Caused the First Depression of the $21^{\text {st }}$ Century, Was a Moral and Political Crisis", in Global Financial Crisis: Causes, Consequences and Impact on Economic Growth, Jeanne Barnett (editor), New York: Nova Publishers, Chapter 2, pp. 15-78.

Kallianiotis, John N. (2013), International Financial Transactions and Exchange Rates: Trade, Investment, and Parities, New York, N.Y.: Palgrave Macmillan.

Kallianiotis, I.N. (2011), "Is the Imposed Global 'Laissez-faire' Socio-economic System Responsible for the Latest Financial Crisis", Journal of Business and Economics, Vol. 2, No. 5, May, pp. 325-353.

Kallianiotis, I.N. (2010), “Were the Current Bear Market and the Recession Predictable?”,International Journal of Applied Business and Economic Research, Vol. 8, No. 1, pp. 37-64.

Kallianiotis, I. N. and Karen Bianchi (2009), "Speculation, Uncertainty, Financial Assets Expected Return and Risk, and Exchange Rate Determination", unpublished manuscript, University of Scranton, November, pages 31.

Kallianiotis, I.N. and Dana M. Harris (2010), “What Went Wrong with our International 'Laissez-faire, Laissezpasser' Economic System?", International Research Journal of Finance and Economics, Issue 50, October, pp. 96122.

Kallianiotis, Ioannis N. and Iordanis Petsas (2008), “Interdependence between U.S. and EU Goods, Money, and Foreign Markets and Spillover Effects", Spoudai, Vol. 58, No. 1-2, pp. 115-147.

Kasibhatla, Krishna M. (2011), "Does the Dollar Call the Tune for Securities and Oil? An Empirical Investigation", The International Journal of Finance, 23 (3), pp. 6870-6880.

Krugman, Paul (2012), "What Went Wrong?", Folio, The Magazine of the Graduate Center, The City University of New York, Winter, pp. 20-23.

Layard, P. R. G. and A. A. Walters (1978), Microeconomic Theory, New York, N.Y.: McGraw-Hill Book Company.

McGuire, Paul and Troy Anderson (2018), Trumpocalypse, New York: Faith Words, Hachette Book Group.

Nechio, Fernanda (2011), “Monetary Policy When One Size Does Not Fit All”, FRBSF Economic Letter, Federal Reserve Bank of San Francisco, 6/14/2011, pp. 1-5.

Papadimitriou, Demitri B. and L. Randall Wray (1999), “Minsky's Analysis of Financial Capitalism”, Working Paper No. 275, Jerome Levy Economics Institute, July.

Pindyck, R.S. and Rubinfeld, D.L. (1981), Econometric Models and Economic Forecasts, McGraw-Hill, New York.

Taylor, John B. (1993). "Discretion versus policy rules in practice". Carnegie-Rochester Conference Series on Public

Policy. Elsevier. 39, December, pp. 195-214. doi:10.1016/0167-2231(93)90009-L. Pdf.

Williamson, John (1983), The Open Economy and the World Economy, New York, N.Y.: Basic Books, Inc.

Williamson, Stephen (2018), “Inflation Control: Do Central Bankers have it Right?”, Review, Federal Reserve Bank of St. Louis, Vol. 100, No. 2, pp. 127-150. 